\title{
Sedimentary provenance study of the post-Early Permian to pre-Early Cretaceous metasedimentary Duque de York Complex, Chile
}

Juan Pablo Lacassie

Barry Roser
Department of Geology, University of Johannesburg, PO Box 524, Auckland Park, Johannesburg 2006, Republic of South Africa Departamento de Geología Económica, Servicio Nacional de Geología y Minería, Av. Santa María 0104, Providencia, Santiago, Chile jlacassie@sernageomin.cl
Francisco Hervé

Departamento de Geología, Universidad de Chile, Casilla 13518, Correo 21, Santiago, Chile
Department of Geoscience, Shimane University, Matsue 690-8504, Japan

roser@riko.shimane-u.ac.jp

\begin{abstract}
The Duque de York Complex constitutes a post-Early Permian to pre-Early Cretaceous metasedimentary succession that crops out at the Madre de Dios and Diego de Almagro archipelagos along the Chilean Patagonian Andes. The petrography and geochemistry of sandstones and mudstones of this complex have been analyzed to characterize its source and depositional tectonic regime. Sandstone modal compositions are dominated by feldspar and, in similar but smaller proportions, by quartz. The mineralogical composition of the sandstones and mudstones is compatible with a low-grade sub-greenschist facies metamorphism. This did not affect significantly the geochemical compositions of these rocks. Nevertheless, the geochemical analyses reveal variable $\mathrm{K}^{+}$enrichment, especially in the mudstones. Chemical Index of Alteration values of the sandstones and mudstones range between 58 and 71 , indicating that the sediment underwent moderate chemical alteration in the source area or during transportation. Sandstone modal compositions are consistent with erosion of the plutonic roots of a magmatic arc. Geochemical provenance indices suggest a relatively evolved source, close in composition to typical continental magmatic arc granodiorite. Deposition of the detritus is most likely to have occurred within an active continental margin. Geochronological, petrographic, and geochemical similarities between the metasediments of the Duke de York Complex, the LeMay Group (Western Antarctica) and the PermianLate Triassic Rakaia terrane (New Zealand) suggest a common geodynamic set-up for these three successions. This likely constituted an extensive late Paleozoic-early Mesozoic active continental margin, possibly along the Antarctic sector of Gondwana.
\end{abstract}

Keywords: Tectonic regime, pre-Late Jurassic, Patagonian Andes, Rakaia terrane, LeMay Group, Gondwana.

RESUMEN

Estudio de proveniencia sedimentaria del Complejo metasedimentario post Pérmico Temprano a pre Cretácico Temprano Duque de York, Chile. El Complejo Duque de York constituye una sucesión metasedimentaria del post Pérmico temprano a pre Cretácico temprano que aflora en los archipiélagos de Madre de Dios y Diego de Almagro 
a lo largo de los Andes Patagónicos de Chile. La petrografía y geoquímica de las areniscas y limolitas de este complejo han sido analizadas para caracterizar su fuente y régimen tectónico depositacional. La composición modal de las areniscas está dominada por feldespato y, en una proporción similar pero menor, por cuarzo. La composición mineralógica de las areniscas y limolitas es compatible con un metamorfismo de bajo grado de la facies sub-esquistos verdes, el cual no afectó significativamente a la composición geoquímica de estas rocas. A pesar de lo anterior, los análisis geoquímicos revelan distintos grados de enriquecimiento en $\mathrm{K}^{+}$, especialmente en las limolitas. El valor del Índice de Alteración Química de las areniscas y limolitas fluctúa entre 58 y 71, lo que indica que el sedimento sufrió una alteración química moderada en su fuente o durante el transporte. Las composiciones modales de las areniscas son concordantes con la erosión de las raíces plutónicas de un arco magmático. Los índices geoquímicos de proveniencia sugieren una fuente relativamente evolucionada, de composición similar a la composición típica de una granodiorita de arco magmático. Los datos indican que la acumulación del material detrítico ocurrió en un margen continental activo. Similitudes geocronológicas, petrográficas y geoquímicas entre los metasedimentos de Duque de York, del Grupo LeMay (Antártica Occidental) y del terreno Rakaia (Pérmico-Triásico Superior; Nueva Zelanda) sugieren un régimen geodinámico común para estas tres sucesiones. Tal régimen probablemente constituyó un extenso margen continental activo durante el Paleozoico superior al Mesozoico temprano, posiblemente a lo largo del segmento Antártico de Gondwana.

Palabras claves: Régimen tectónico, pre-Jurasico Tardío, Andes Patagónicos, terreno Rakaia, Grupo LeMay, Gondwana.

\section{INTRODUCTION}

The Duque de York Complex (DYC) is a postEarly Permian to pre-Early Cretaceous metasedimentary succession consisting of sandstones, mudstones, and subsidiary conglomerates. It crops out in the Madre de Dios and Diego de Almagro archipelagos (49-52 $\left.{ }^{\circ} \mathrm{S}\right)$, at Ramirez and Contreras Islands and at Desolación Island, along the Chilean Patagonian Andes (Fig. 1). Forsythe and Mpodozis (1983) regarded the DYC as a continent-derived detrital succession that was unconformably deposited over two other units as they approached the continental margin of Gondwana. These other units are the coeval Late Carboniferous-earliest Permian Tarlton Limestone (Douglass and Nestell, 1976) and the Denaro Complex. All three units were then tectonically amalgamated to the forearc of the former margin by subduction processes.

The previous petrographic and geochemical study of Faúndez et al. (2002) suggests that the DYC was deposited at an active continental margin which contained sedimentary, plutonic, and volcanic rocks, in a subduction zone and/or strike slip setting. However, the petrographic characteristics of many of the sandstones examined in that study are also compatiblewith a continental or recycled provenance(Faúndez et al., 2002).

In this paper we present new geological, petrographic, and geochemical data for the DYC, obtained from a larger number of samples with more constrained granulometry than those in the previous study of Faúndez etal. (2002). The new data provides information of the characteristics of the DYC source and of its depositional basin. This study thus contributes to the understanding of a portion of the 'Pacific' margin of Gondwanathatwascontinuous throughWestAntarctica to New Zealand in the late Paleozoic to early Mesozoic (e.g., Veevers et al., 1994).

\section{GEOLOGICAL SETTING}

\section{GENERAL}

The stratigraphy and structure of the Madre de Dios archipelago $\left(49-52^{\circ} \mathrm{S}\right)$ were studied by Forsythe and Mpodozis (1983) who distinguished the Denaro Complex, composed of metabasalt and chert, from the Tarlton Limestone and the Duque de York
Complex (DYC; sandstone, siltstone, shale and conglomerate). These units are intruded by the Patagonian Batholith (Figs. 1 and 2). According to Ling et al. (1985) the Tarlton Limestone and the Denaro Complex were deposited in a mid-ocean ridge environment, which is in agreement with the E-MORB signature of the Denaro Complex pillow basalts (Hervé 
et al., 1999b). All three units were then tectonically amalgamated to the forearc of this margin by subduction processes (Forsythe and Mpodozis, 1983) before the Early Cretaceous intrusion of the Patagonian Batholith. The DYC was deposited unconformably over the other two units as they approached the continental margin of Gondwana.

At Tarlton Island the contact between the DYC and the Tarlton Limestone seems to be conformable (Forsythe and Mpodozis, 1983). However, in the tectonically inverted stratigraphic succession of Seno (Fjord) Soplador a disconformity separates the DYC from a Tarlton Limestone paleo-karstic surface (Hervé etal., 1999a; Lacassie, 2003; Figs. 1 and 3a). Therefore, the depositional age of the DYC is constrained by the Late Carboniferous-earliest Permian age of the Tarlton
Limestone (Douglass and Nestell, 1976) and the Early Cretaceous intrusion of the PatagonianBatholith. Detrital zircon U-Pb SHRIMP age determinations in two DYC metasandstones from the Madre de Dios archipelago and one from Desolación Island (Hervé et al., 1999a; Figs. 1 and 2) reveal a prominent late Early Permian population (ca. 270Ma) of zircons of igneous derivation, along with other two components of late Proterozoic and early Paleozoic age (Hervé et al., 1999b). This occurrence of late Early Permian zircons can be interpreted as the first flush of detritus from a new igneous complex being developed in the continental margin. This interpretation implies that the continent-derived sediments of the DYC, presumably close to the continental margin, covered the oceanic assemblages as early as late Early Permian times (Faúndezetal., 2002).

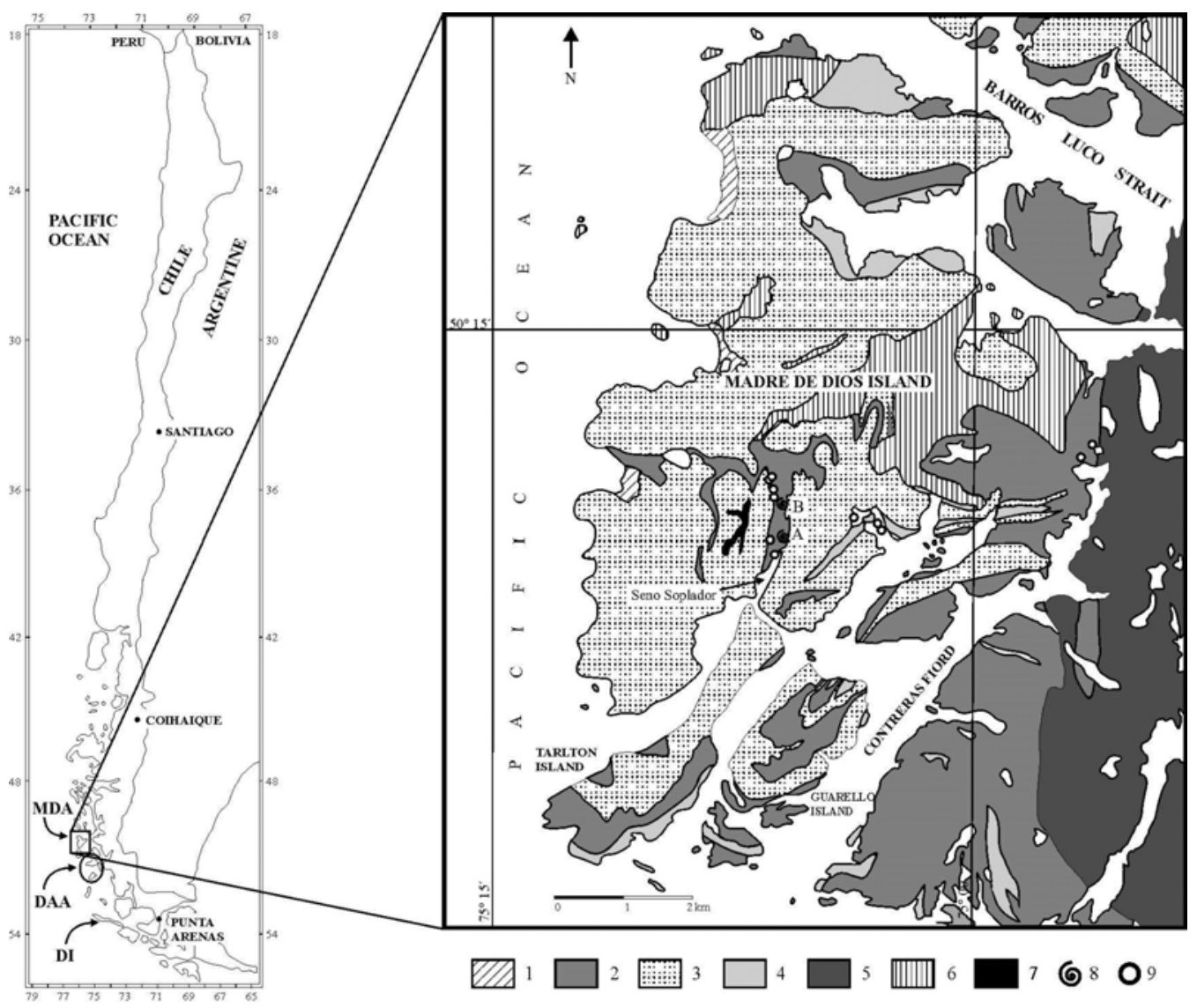

FIG. 1. Geologic map of Madre de Dios Island (modified after Forsythe and Mpodozis, 1983): 1. Quaternary; 2. Patagonian Batholith (Late Jurassic-Early Cretaceous); 3. Tarlton Limestone (Late Carboniferous-Early Permian); 4. Denaro Complex (Late Carboniferous-Early Permian); 5. Duque de York Metamorphic Complex (post-Early Permian to pre-Early Cretaceous); 6. Pre-Late Jurassic undifferentiated basement; 7. Sill (post-Early Permian); 8. Fossiliferous locality; 9. Sampling locality; MDA: Madre de Dios Archipelago; DAA: Diego de Almagro Archipelago; DI: Desolación Island. 


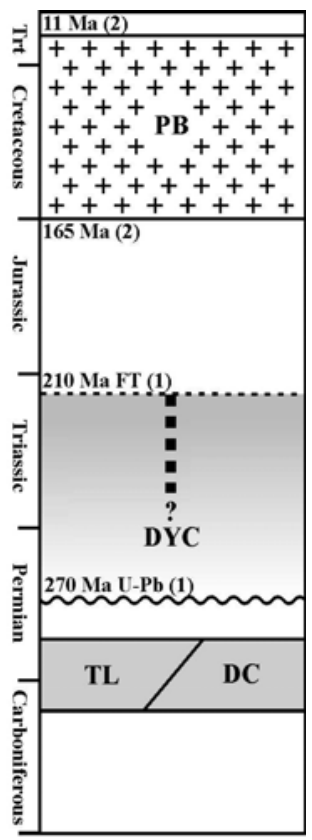

FIG. 2. Stratigraphic table showing correlation between different units at the study area. PB: Patagonian Batholith; DYC: Duque de York Complex; TL: Tarlton Limestone; DC: Denaro Complex; FT: Detrital zircon fission track age; U-Pb: Detrital zircon U-Pb age. 1. Thomson et al., 2000; 2. Bruce et al., 1991. The dashed line represents the temporal extension of the DYC metamorphism. Slightly modified after Faúndez et al. (2002).

The Denaro Complex, Tarlton Limestone, and the DYC also crop out in the Diego de Almagro archipelago (51 30 'S; Fig. 1). In this area they are in tectonic contact (Seno Arcabuz Strain Shear Zone mylonites; Olivares etal., 2003) with the Almagro Complex, which includes highly deformed blue schists, green schists, mica schists, ultramafic rocks and cherts (Forsythe et al., 1981; Willner etal., 2004). Detrital zircons from a DYC metasandstone collected from this area and in Desolacion Island are not younger than $265 \mathrm{Ma}$ (Early Permian; Hervé et al., 1999b).

\section{STUDY AREA}

The DYC succession in the study area (Fig. 1) consists of metaturbidites of very low metamorphic grade. It is composed of rhythmic intercalations of light grey sandstones and black to grey mudstones and sandstones between massive outcrops of polymict conglomerate beds, occasionally normally graded. Bed thicknesses range from millimeter to meter scale (Fig. 3a). Sedimentary structures of the sandstones such as bioturbated beds, flame structures, flute and groove casts attesting to erosive current action are locally preserved, and sandstone load balls in mudstone indicate post-depositional instability. Most of the succession is structureless, but planar, crossand convolute-laminations were observed together with rare mesoscopic slumping and synsedimentary faulting. The conglomerates are matrix-supported (estimated $35-50 \%$ matrix). Their clasts are usually rounded, range in size from $<1$ to $15 \mathrm{~cm}$, and consist of sandstones, acid plutonic and volcanic rocks, and limestones and chert, in decreasing order of frequency. Some conglomerate, fine sandstone, and mudstone beds contain ovoid millimeter scale fossils that correspond to fusulinids (Hamish Campbell, written comm.), which have been also identified by Douglass and Nestell (1976) in Tarlton Limestone outcrops on Tarlton and Guarello islands (Fig. 1).

Trace fossils have been observed at two localities, distributed parallel to sub-vertical to the bedding planes of fine-grained greywacke and mudstone horizons (localities A and B of Fig. 1). The ichnofossil assemblage at locality $A$ is characterized by occurrence of Planolites isp., Palaeophycus isp. and Ancorichnus isp. (Florencio Aceñolaza, written comm.), whereas that at locality $B$ is characterized by the occurrence of Scalarituba isp. and Chondrites isp. (Hamish Campbell, written comm.).

Stratigraphic relations are obliterated due to complex tectonic imbrication between the DYC, Tarlton Limestone and the Denaro Complex as a result of two deformation events (Forsythe and Mpodozis, 1983). However, a paleo-karstic surface was recognized close to the Tarlton Limestone-DYC contact, presumably the same as that described by Hervé et al. (1999a) at the west coast of Seno Soplador (Fig. 3a). The surface consists of a breccia of limestone clasts surrounded by a calcareous matrix, which locally contains metric to decameter scale lenses of fossiliferous black mudstone (Fig. 3b). The rest of the Tarlton Limestone is a highly homogeneous succession of meter-thick white limestone beds (Lacassie, 2003) that presents a variety of surface (Fig. 3c) and underground erosional features, the latter including a vast network of underground tunnels, chambers and sinkholes. In the Seno Soplador area the Tarlton Limestone is intruded by a kilometer-scale basic sill (Fig. 1); by concordant, highly weathered, centimeter scale dikes; and by discordant, meter scale basic dikes, which are usually sub-vertical, northwesttrending, and intrude the DYC. 

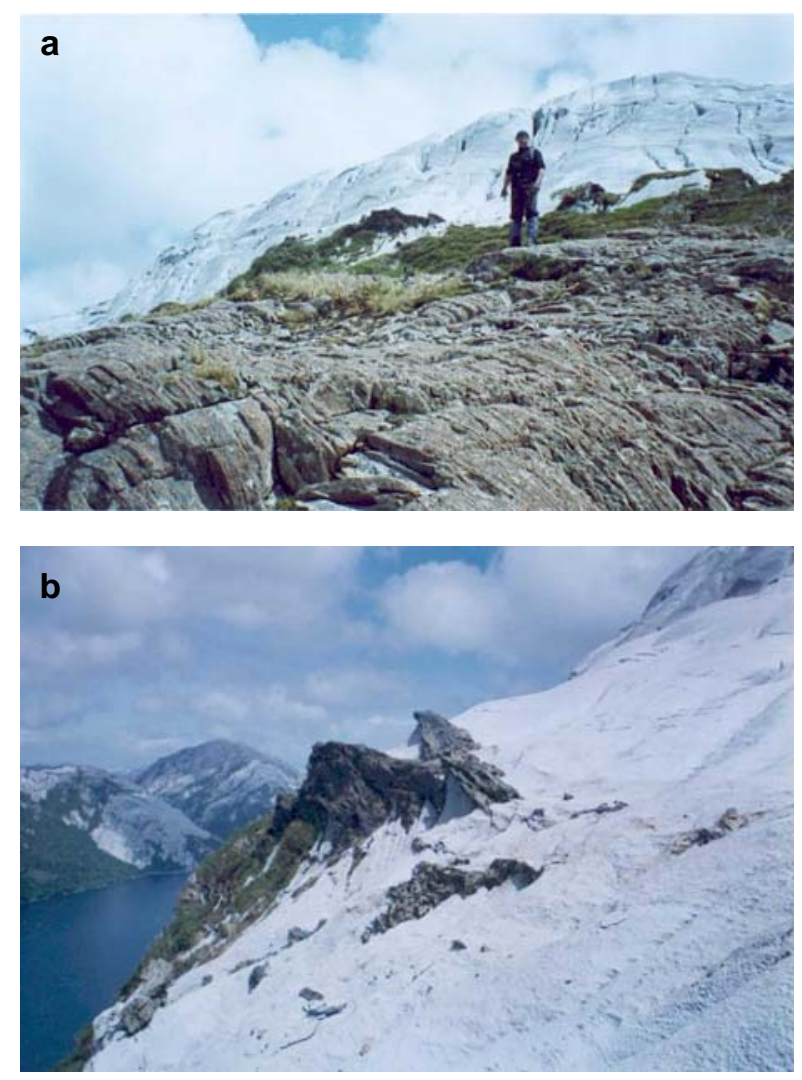

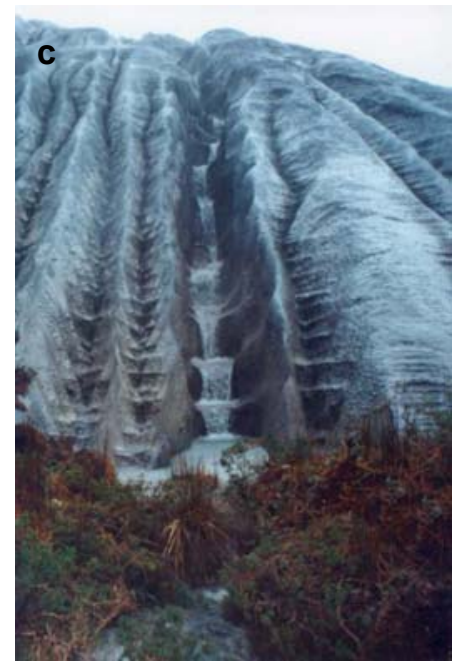

FIG. 3. Tectonically inverted stratigraphic succession of Seno Soplador. A. Close to its base the DYC succession is composed of rhythmic intercalations of centimeter scale sandstone and mudstone beds. The TL-DYC contact is covered by vegetation as shown in the upper part of the figure; $\mathbf{B}$. Close to the TL-DYC contact a TL paleo-karstic surface contains metric to decameter scale lenses of fossiliferous black mudstone; C. Stairshaped waterfall corresponding to one of the characteristic surface erosional features of the TL.

\section{SAMPLES AND METHODS}

The analyzed DYC samples were collected from eleven localities in the Madre de Dios archipelago (Fig. 1). Eighteen DYC sandstones and mudstones were examined in thin section. Five sandstones and one sandy mudstone were selected for point-count analysis on the basis of their low deformation and limited recrystallization. Sand-sized grains of monocrystalline quartz, feldspars, and lithic fragments (parameters Q, $\mathrm{F}$ and $\mathrm{L}$, respectively) were counted following the Gazzi-Dickinson method (Ingersoll et al., 1984). For each thin section, 300 points were counted, except for sample UP-109, for which only 200 points were counted.

Whole-rockmajor and trace elementconcentrations of five DYC sandstones and six mudstones were determined by ICP-AES (Perkin-Elmer P-430) at the Geology Department, Universidad de Chile (Table 1). Detection limits were $0.1 \%$ for major elements; 2 ppm for Th and Nb; 1 ppm for $\mathrm{Ba}, \mathrm{Sr}, \mathrm{Zr}, \mathrm{Y}, \mathrm{Cr}, \mathrm{V}, \mathrm{Ni}$, $\mathrm{Co}, \mathrm{Sc}, \mathrm{Cu}, \mathrm{Zn}, \mathrm{Hf}, \mathrm{La}, \mathrm{Ce}, \mathrm{Nd}$, and Sm; 0.1 ppm for
Eu, Gd, Dy, Ho, Er, and Yb; and 0.05 ppm for Lu. For all plots and comparisons the data were normalized to $100 \%$ on a loss-on-ignition (LOI) free basis.

For comparative purposes, one dataset was built using selected sandstone analyses from the literature (Table 2). The sandstone suites chosen have wellestablished provenance type, not determined solely by geochemical means, and metamorphic grade lower than upper greenschist to lower amphibolite facies. These include sandstones of each first-order provenance group defined by Roser and Korsch (1988): P1 (mafic) first-cyclebasaltic and lesser andesitic detritus; P2 (intermediate) dominantly andesitic detritus; P3 (felsic) felsic plutonic and volcanic detritus; and P4 (recycled) mature polycyclic quartzose detritus. The data were drawn from different geographic regions and from successions of differing age. The dataset comprises 180 sandstone analyses with concentration data (wt.\%) for the major and minor oxides in all samples (Table 2). This dataset was analyzed using 
a discriminant function analysis technique to construct a major element-based comparative diagram. The discriminant function analysis technique can be used to derive a set of linear functions based on multiple variables, designed to achieve best separation between pre-defined groups of standard data (Roser and Korsch, 1988). The method is described in detail by Le Maitre (1982).

TABLE 1. GEOCHEMICAL ANALYSES OF THE DYC ROCKS.

\begin{tabular}{|c|c|c|c|c|c|c|c|c|c|c|c|c|c|c|c|}
\hline $\begin{array}{c}\text { Sample } \\
\text { Lith. }\end{array}$ & $\begin{array}{c}\text { 132B } \\
\text { sd }\end{array}$ & $\begin{array}{c}111 \\
\text { sd }\end{array}$ & $\begin{array}{l}119 \\
\text { sd }\end{array}$ & $\begin{array}{l}107 \\
\text { sd }\end{array}$ & $\begin{array}{l}115 \\
\text { sd }\end{array}$ & Avg sd & std & $\begin{array}{l}109 \\
\text { md }\end{array}$ & $\begin{array}{l}110 \\
\mathrm{md}\end{array}$ & $\begin{array}{l}112 \\
\mathrm{md}\end{array}$ & $\begin{array}{l}121 \\
\mathrm{md}\end{array}$ & $\begin{array}{l}136 \\
\mathrm{md}\end{array}$ & $\begin{array}{l}137 \\
\text { md }\end{array}$ & Avg md & std \\
\hline \multicolumn{16}{|c|}{ Major elements (wt.\%) } \\
\hline $\mathrm{SiO}_{2}$ & 72.28 & 75.07 & 74.47 & 74.15 & 78.23 & 74.84 & 2.17 & 68.03 & 62.39 & 64.86 & 66.80 & 58.54 & 64.67 & 64.22 & 3.39 \\
\hline $\mathrm{TiO}_{2}$ & 0.60 & 0.53 & 0.52 & 0.52 & 0.42 & 0.52 & 0.06 & 0.78 & 0.98 & 0.88 & 0.79 & 1.11 & 0.96 & 0.92 & 0.12 \\
\hline $\mathrm{Al}_{2} \mathrm{O}_{3}$ & 14.58 & 13.46 & 13.75 & 14.09 & 12.08 & 13.59 & 0.94 & 16.70 & 19.98 & 19.12 & 17.32 & 20.65 & 18.36 & 18.69 & 1.52 \\
\hline $\mathrm{FeO}$ & 2.58 & 3.00 & 2.52 & 3.05 & 1.93 & 2.62 & 0.45 & 4.99 & 5.74 & 5.33 & 4.12 & 6.72 & 5.28 & 5.36 & 0.86 \\
\hline $\mathrm{MnO}$ & 0.03 & 0.03 & 0.04 & 0.06 & 0.03 & 0.04 & 0.01 & 0.07 & 0.07 & 0.04 & 0.02 & 0.08 & 0.07 & 0.06 & 0.02 \\
\hline $\mathrm{MgO}$ & 1.47 & 1.15 & 1.36 & 1.34 & 0.80 & 1.22 & 0.26 & 2.16 & 2.16 & 2.21 & 2.56 & 2.62 & 2.35 & 2.34 & 0.20 \\
\hline $\mathrm{CaO}$ & 1.56 & 0.95 & 1.17 & 0.49 & 1.05 & 1.04 & 0.39 & 0.55 & 0.71 & 1.13 & 1.90 & 2.35 & 1.13 & 1.29 & 0.70 \\
\hline $\mathrm{Na}_{2} \mathrm{O}$ & 2.58 & 3.24 & 3.13 & 3.38 & 3.63 & 3.19 & 0.39 & 2.32 & 1.71 & 1.60 & 1.81 & 2.20 & 1.25 & 1.81 & 0.39 \\
\hline LOI & 2.54 & 2.36 & 2.18 & 2.45 & 1.46 & & & 3.82 & 4.96 & 4.63 & 5.14 & 2.93 & 3.34 & & \\
\hline Sum & 99.93 & 99.84 & 99.78 & 99.75 & 99.69 & & & 99.70 & 99.95 & 99.63 & 99.82 & 99.66 & 99.96 & & \\
\hline C.I.A & 60.18 & 60.87 & 60.15 & 63.91 & 57.66 & 60.55 & 2.24 & 69.52 & 71.15 & 68.09 & 63.62 & 62.61 & 64.32 & 66.55 & 3.50 \\
\hline
\end{tabular}

Trace elements (ppm)

\begin{tabular}{|c|c|c|c|c|c|c|c|c|c|c|c|c|c|c|c|}
\hline $\mathrm{La}$ & 31.83 & 22.57 & 27.66 & 34.94 & 28.50 & 29.10 & 4.66 & 36.50 & 31.72 & 40.00 & 29.57 & 39.28 & 36.22 & 35.55 & 4.14 \\
\hline $\mathrm{Ce}$ & 72.90 & 55.40 & 61.48 & 76.05 & 62.10 & 65.59 & 8.60 & 88.65 & 74.01 & 88.42 & 64.43 & 90.97 & 82.80 & 81.55 & 10.37 \\
\hline $\mathrm{Nd}$ & 30.80 & 25.65 & 25.61 & 35.97 & 27.49 & 29.10 & 4.38 & 39.63 & 34.89 & 40.00 & 29.57 & 40.32 & 35.19 & 36.60 & 4.22 \\
\hline $\mathrm{Sm}$ & 5.32 & 4.46 & 4.36 & 6.19 & 4.61 & 4.99 & 0.77 & 6.40 & 6.60 & 7.55 & 5.28 & 6.98 & 6.82 & 6.60 & 0.76 \\
\hline $\mathrm{Eu}$ & 1.16 & 0.98 & 0.96 & 1.13 & 0.93 & 1.03 & 0.11 & 1.23 & 1.22 & 1.43 & 1.24 & 1.55 & 1.40 & 1.34 & 0.14 \\
\hline $\mathrm{Gd}$ & 4.04 & 3.28 & 3.34 & 4.81 & 3.25 & 3.74 & 0.68 & 5.31 & 4.77 & 5.37 & 4.57 & 5.80 & 5.32 & 5.19 & 0.45 \\
\hline Dy & 3.62 & 3.31 & 3.24 & 4.45 & 3.30 & 3.58 & 0.51 & 5.18 & 4.85 & 5.44 & 4.49 & 5.55 & 5.28 & 5.13 & 0.40 \\
\hline Ho & 0.72 & 0.67 & 0.67 & 0.81 & 0.69 & 0.71 & 0.06 & 0.92 & 0.70 & 1.14 & 0.92 & 1.09 & 1.05 & 0.97 & 0.16 \\
\hline $\mathrm{Er}$ & 1.92 & 1.91 & 1.82 & 2.26 & 1.76 & 1.93 & 0.19 & 2.36 & 2.50 & 2.83 & 2.45 & 2.97 & 2.84 & 2.66 & 0.25 \\
\hline $\mathrm{Yb}$ & 1.95 & 1.88 & 1.80 & 2.17 & 1.78 & 1.92 & 0.16 & 2.26 & 2.54 & 2.84 & 2.44 & 2.99 & 2.89 & 2.66 & 0.29 \\
\hline $\mathrm{Lu}$ & 0.28 & 0.27 & 0.28 & 0.32 & 0.25 & 0.28 & 0.02 & 0.32 & 0.36 & 0.39 & 0.37 & 0.48 & 0.45 & 0.39 & 0.06 \\
\hline$Y$ & 17.5 & 15.4 & 16.4 & 22.6 & 17.3 & 17.8 & 2.8 & 22.9 & 23.3 & 26.3 & 23.2 & 28.9 & 25.9 & 25.1 & 2.4 \\
\hline Sc & 8.2 & 7.2 & 7.2 & 7.2 & 5.1 & 7.0 & 1.1 & 12.5 & 14.8 & 13.7 & 11.6 & 17.6 & 15.5 & 14.3 & 2.2 \\
\hline $\mathrm{Hf}$ & 4.5 & 4.6 & 5.5 & 6.3 & 5.5 & 5.3 & 0.7 & 4.6 & 1.5 & 2.5 & 3.0 & 1.7 & 2.8 & 2.7 & 1.1 \\
\hline $\mathrm{Nb}$ & 11.3 & 9.2 & 9.2 & 8.2 & 8.1 & 9.2 & 1.3 & 11.5 & 13.7 & 14.7 & 13.7 & 13.4 & 13.5 & 13.4 & 1.1 \\
\hline Th & 10.3 & 9.2 & 10.2 & 10.3 & 9.2 & 9.8 & 0.6 & 12.5 & 12.7 & 14.7 & 12.7 & 13.4 & 13.5 & 13.3 & 0.8 \\
\hline $\mathrm{Zn}$ & 86 & 54 & 49 & 60 & 44 & 59 & 17 & 113 & 112 & 103 & 98 & 159 & 122 & 118 & 22 \\
\hline Co & 9 & 6 & 6 & 10 & 5 & 7 & 2 & 11 & 12 & 11 & 12 & 20 & 16 & 13 & 4 \\
\hline $\mathrm{Ni}$ & 15 & 15 & 10 & 13 & 5 & 12 & 4 & 21 & 23 & 23 & 23 & 28 & 29 & 25 & 3 \\
\hline $\mathrm{Ba}$ & 585 & 431 & 543 & 308 & 366 & 447 & 117 & 480 & 560 & 758 & 401 & 786 & 776 & 627 & 168 \\
\hline $\mathrm{Cr}$ & 32 & 38 & 25 & 21 & 23 & 28 & 7 & 52 & 69 & 82 & 63 & 88 & 66 & 70 & 13 \\
\hline V & 71 & 51 & 50 & 58 & 46 & 55 & 10 & 108 & 118 & 151 & 116 & 175 & 135 & 134 & 25 \\
\hline $\mathrm{Cu}$ & 7 & 7 & 8 & 6 & 6 & 7 & 1 & 17 & 25 & 15 & 12 & 17 & 18 & 17 & 5 \\
\hline $\mathrm{Sr}$ & 257 & 246 & 266 & 185 & 310 & 253 & 45 & 94 & 42 & 129 & 61 & 212 & 124 & 111 & 60 \\
\hline $\mathrm{Zr}$ & 254 & 284 & 285 & 320 & 312 & 291 & 26 & 197 & 138 & 179 & 188 & 148 & 169 & 170 & 23 \\
\hline
\end{tabular}

Lith: lithology; sd: sandstone; md: mudstone; Avg sd: average sandstone; Avg md: average mudstone; std: standard deviation; LOI: loss on Ignition; Sum: original major element totals (hydrous basis); C.I.A: chemical index of alteration. 
TABLE 2. LITERATURE DERIVED GEOCHEMICAL DATA.

\begin{tabular}{|c|c|c|c|c|}
\hline Pt & $\%$ & $\mathbf{N}$ & Sedimentary succesion & Reference \\
\hline P1 & 8 & 14 & Baldwin Formation (Australia) & Roser and Korsch (1988) \\
\hline \multirow{3}{*}{ P2 } & \multirow{3}{*}{34} & 5 & Caples and Murihiku terranes (New Zealand) & Frost and Coombs (1989) \\
\hline & & 13 & Izu-Bonin Arc (Japan) & Gill et al. (1994) \\
\hline & & 43 & Perolus and Waipapa terranes (New Zealand) & Roser and Korsch (1988) \\
\hline \multirow{4}{*}{ P3 } & \multirow{4}{*}{46} & 5 & Gramscatho Group (England) & Floyd and Leveridge (1987) \\
\hline & & 2 & Torlesse terrane (New Zealand) & Frost and Coombs (1989) \\
\hline & & 11 & Chelmsford Formation (USA) & McDaniel et al. (1994) \\
\hline & & 65 & Torlesse terrane (New Zealand) & Roser and Korsch (1988) \\
\hline \multirow[b]{2}{*}{ P4 } & \multirow[b]{2}{*}{12} & 2 & Welsh Basin (England) & McCann (1991) \\
\hline & & 20 & Greenland Group (New Zealand) & Roser and Korsch (1988) \\
\hline Total & 100 & 180 & & \\
\hline
\end{tabular}

Pt: Provenance type; \%: Relative percentage; $\mathbf{N}$ : Number of samples of each sedimentary succession.

\section{PETROGRAPHY}

The DYC sandstones are fine-grained to coarsegrained feldspar-quartz, quartz-feldspar and, in minor proportion, rock fragment-feldspar-quartz sandstones (Friedman and Sanders, 1978), with angular to subangular sand-sized clasts that display varying degrees of alteration. In terms of QFL parameters the framework mineralogy is characterized by angular to sub-angular, non-undulose, monocrystalline quartz (23-36\%, average $29 \pm 6 \%$ ), angular feldspar grains (42-58\%, average $52 \pm 6 \%$, and angular lithic fragments $(12-23 \%$, average $18 \pm 5 \%$ ). The lithics comprise acid volcanic (rhyolite to dacite) and clastic sedimentary (sandstone to mudstone) clasts, either type predominating in individual samples. Fresh feldspar grains usually display albite twinning or perthitic texture, whereas altered feldspar grains are mainly replaced by sericite, with epidote and calcite as minor alteration products. Lithic grains have usually suffered hematite or sericite alteration, and the most altered examples are difficult to distinguish from the matrix. The most common detrital minerals are muscovite and biotite. Minor amounts of detrital zircon, sphene, epidote (zoisite), tourmaline, apatite, garnet, and opaques are also present with a combined abundance of less than 1 $\%$ vol. Mostzircongrains are idiomorphic. Matrixconsists of chlorite and other phyllosilicates (mainly illite) and its content varies between 5 and 25\%. The DYC mudstones consist of a mixture of chlorite and other phyllosilicates, and usually contain quartz-feldspar lamellae. The DYC samples have a low-grade mineral paragenesis consistent with sub-greenschist metamorphism, and heterogeneous deformation expressed as stylolitic bands, and bending and kinking of detrital biotite and muscovite. Two samples collected at the northern tip of Contreras Fiord (Fig. 1) contain cordierite overprinting the low-grade paragenesis, resulting from the thermometamorphic effect of the Patagonian Batholith intrusives.

A QFL diagram (Dickinson et al., 1983) shows the DYC sandstones plot in the dissected-arc field, although two samples fall near the boundary between the dissected and the transitional arc fields (Fig. 4).

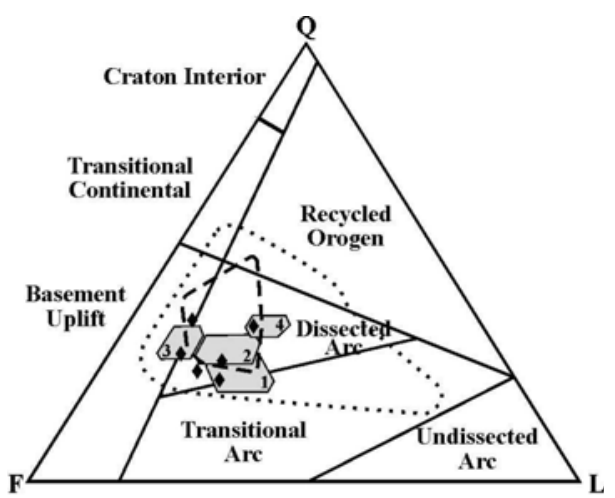

FIG. 4. QFL diagram (Dickinson et al., 1983). Q. Total Quartz; F. Total Feldspars; L. Total Lithics. Dashed line. LeMay Group sandstone distribution (Tranter, 1991). Dotted line. LeMay Group sandstone distribution(Willan, 2003). Shaded hexagons. One standard deviation fields for Permian-Late Triassic Rakaia terrane petrofacies (PF1-PF4; MacKinnon, 1983). Black diamonds. DYC sandstones. 


\section{GEOCHEMISTRY}

\section{MAJOR ELEMENTS}

In terms of major elements the DYC rocks show systematic geochemical contrast between sandstone and mudstone (Table 1). The sandstones have higher average concentrations of $\mathrm{SiO}_{2}(74.84 \pm 2.17 \mathrm{wt} \%)$ and $\mathrm{Na}_{2} \mathrm{O}(3.19 \pm 0.39 \mathrm{wt} \%)$ than the mudstones (64.22 \pm 3.39 wt. \% and $1.81 \pm 0.39$ wt. $\%$, respectively). Conversely, the sandstones have lower average $\mathrm{TiO}_{2}(0.52 \pm 0.06 \mathrm{wt} \%), \mathrm{Al}_{2} \mathrm{O}_{3}(13.59 \pm 0.94)$, $\mathrm{Fe}_{2} \mathrm{O}_{3} \mathrm{t}+\mathrm{MgO}(2.44 \pm 0.63)$, and $\mathrm{K}_{2} \mathrm{O}(1.88 \pm 0.55)$ than the mudstones $(0.92 \pm 0.12,18.69 \pm 1.52$, $4.08 \pm 0.56$, and $4.00 \pm 0.70$ wt. $\%$ respectively).

The chemical index of alteration (CIA; Nesbitt and Young, 1982) has been used as an indicator for bulk chemical changes due to weathering in the source area or en route to the basin. CIA values of the DYC rocks range between 58 and 71 (Table 1 ), with the sandstones having lower values (58-64, average 60.55 \pm 2.24 ) than the mudstones (63-71, average 66.55 \pm 3.50 ).

\section{TRACE ELEMENTS}

The DYC mudstones tend to be enriched in most trace elements relative to the DYC sandstones (Table 1). This is particularly marked for thoseelements enriched in basic rocks and associated mafic minerals, as shown by the average concentrations of $\mathrm{Cr}(28 \pm 7$ and $70 \pm 13$ ppm, for sandstones and mudstones respectively),

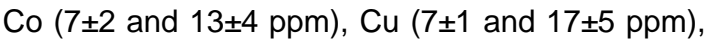
Sc $(7.0 \pm 1.1$ and $14.3 \pm 2.2 \mathrm{ppm}), \mathrm{V}(55 \pm 10$ and $134 \pm 25 \mathrm{ppm})$ and $\mathrm{Zn}(59 \pm 17$ and $118 \pm 22 \mathrm{ppm})$. A similar pattern is shown by the average concentrations of high-field strength elements such as $\mathrm{Y}, \mathrm{Nb}$, and Th, although the contrasts are smaller. Average $\mathrm{Y}, \mathrm{Nb}$, and

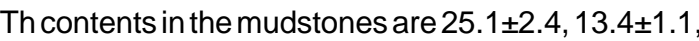
and $13.3 \pm 0.8 \mathrm{ppm}$ respectively, compared to $17.8 \pm 2.8,9.2 \pm 1.3$, and $9.8 \pm 0.6$ for the sandstones. The mudstones are depleted relative to the sandstones only for $\mathrm{Zr}$, Hf and $\mathrm{Sr}$, with averages of $170 \pm 23$, 2.7 \pm 1.1 , and $111 \pm 60$ ppm compared to $291 \pm 26$ (Zr), $5.3 \pm 0.7(\mathrm{Hf})$ and $253 \pm 45(\mathrm{Sr})$ in the sandstones.

Chondrite-normalized REE distribution patterns of the DYC sandstones and mudstones (Fig. 5) show LREE enrichment (high average ( $\mathrm{La} / \mathrm{Yb}$ )n of 10.2 and 9.1, respectively), flat HREE distributions (average $(\mathrm{Gd} / \mathrm{Yb}) \mathrm{n}$ of 1.6) and persistent negative Euanomalies (average Eu/Eu* of $0.74 \pm 0.06$ and $0.70 \pm 0.05$ respectively; Table 3 ). The DYC mudstones present higher $\Sigma$ REE contents and slightly larger Eu-anomalies than the sandstones, although there is a considerable overlap between the lithotypes and no systematic difference between their REE patterns is apparent (Fig. 5).

TABLE 3. COMPARISON OF VALUES OF DISTINCTIVE GEOCHEMICAL PARAMETERS FOR THE AVERAGE DYC ROCKS WITH THE CHARACTERISTIC VALUES OF REPRESENTATIVE PHANEROZOIC GREYWACKES FROM VARIOUS TECTONIC SETTINGS AND WITH THE AVERAGE VALUES FOR THE P1-P4 PROVENANCE GROUPS.

\begin{tabular}{|c|c|c|c|c|c|c|}
\hline \multicolumn{7}{|c|}{ DYC vs. Provenance groups } \\
\hline & DYC sd & DYC md & P1 & P2 & P3 & P4 \\
\hline \multicolumn{7}{|c|}{ Major element parameters } \\
\hline $\mathrm{Fe}_{2} \mathrm{O}_{3} \mathrm{t}+\mathrm{MgO}$ & 5.0 & 7.1 & 15.1 & 10.0 & 4.7 & 4.5 \\
\hline $\mathrm{SiO}_{2} / \mathrm{Al}_{2} \mathrm{O}_{3}$ & 5.5 & 3.5 & 3.2 & 3.8 & 5.1 & 7.9 \\
\hline $\mathrm{K}_{2} \mathrm{O} / \mathrm{Na}_{2} \mathrm{O}$ & 0.6 & 2.3 & 0.3 & 0.4 & 0.7 & 2.0 \\
\hline $\mathrm{Al}_{2} \mathrm{O}_{3} /\left(\mathrm{CaO}+\mathrm{Na}_{2} \mathrm{O}\right)$ & 3.2 & 6.3 & 1.7 & 2.1 & 2.6 & 5.4 \\
\hline$N$ & 5 & 6 & 84 & 121 & 300 & 198 \\
\hline \multicolumn{7}{|l|}{ Trace element parameters } \\
\hline Th/Sc & 1.4 & 0.9 & 0.1 & 0.3 & 1.3 & 1.5 \\
\hline $\mathrm{Zr} / \mathrm{Th}$ & 29.7 & 12.9 & 44.9 & 28.8 & 17.4 & 17.3 \\
\hline$N$ & 5 & 6 & 60 & 99 & 213 & 130 \\
\hline \multicolumn{7}{|c|}{ DYC vs. Phanerozoic greywackes } \\
\hline & DYC sd & DYC md & OIA & $\mathrm{CIA}$ & ACM & PM \\
\hline \multicolumn{7}{|l|}{ REE elements parameters } \\
\hline $\mathrm{Eu} / \mathrm{Eu}^{*}$ & 0.74 & 0.70 & 1.04 & 0.80 & 0.60 & 0.55 \\
\hline$(\mathrm{La} / \mathrm{Yb}) \mathrm{n}$ & 10.24 & 9.07 & 2.80 & 7.50 & 8.30 & 10.80 \\
\hline$(\mathrm{Gd} / \mathrm{Yb}) \mathrm{n}$ & 1.57 & 1.59 & 1.31 & 1.49 & 1.26 & 2.75 \\
\hline$N$ & 5 & 6 & 11 & 32 & 10 & 15 \\
\hline
\end{tabular}

DYC sd: Average DYC sandstone; DYC md: Average DYC mudstone; $\boldsymbol{N}$ : Number of samples used for the calculation of the average values. Average values for the P1-P4 provenance groups (Roser and Kosch, 1988) from Lacassie et al. (2004). Data for greywackes of various tectonic settings from Bhatia (1985). OIA: Oceanic Island Arc; CIA: Continental Island Arc; ACM: Active Continental Margin; PM: Passive Margin; REE chondrite-normalizing factors from Taylor and McLennan (1985). 

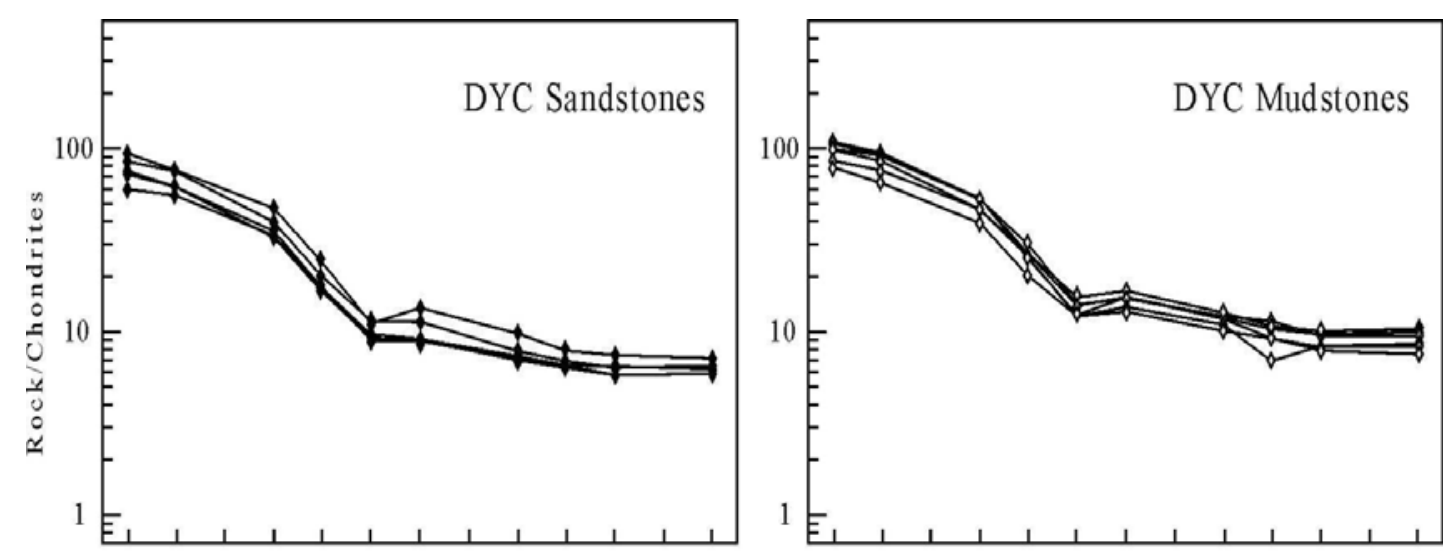

FIG. 5. Chondrite-normalized REE diagrams for DYC sandstones and mudstones. Chondrite normalizing factors from Taylor and McLennan (1985).

\section{DISCRIMINANT DIAGRAMS}

A variety of major and trace element-based diagrams have been applied to discriminate the nature of the source area and the tectonic setting of the depositional basin of DYC. These include published schemes and the discriminants developed in this work.

In the A-CN-K diagram of Nesbitt and Young
(1984) the DYC samples display a broadly linear trend that intersects the primary source compositions of granodiorite or tonalite (Fig. 6). The overall trend of the DYC data is inclined relative to the ideal weathering line expected for sediments derived from granodiorites, and trends towards illite-muscovite composition. The mudstones consistently plot at higher $\mathrm{K}$ values than the sandstones.

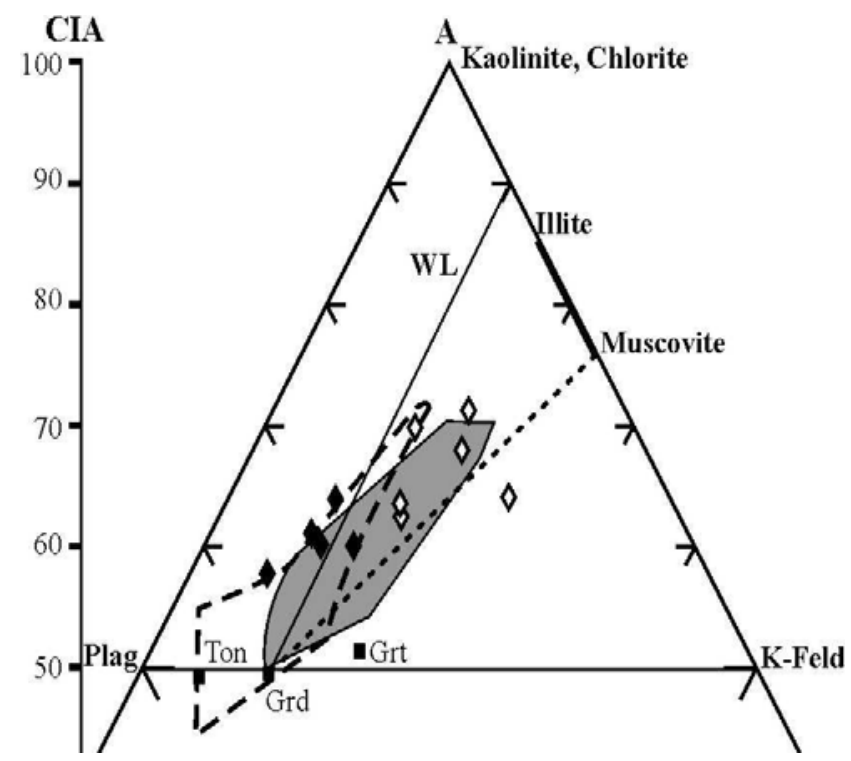

FIG. 6. A-CN-K diagram A. $\mathrm{Al}_{2} \mathrm{O}_{3}, \mathrm{CN} \cdot \mathrm{CaO}+\mathrm{Na}_{2} \mathrm{O}, \mathrm{K} \cdot \mathrm{K} 2 \mathrm{O}$, in molecular proportions (Nesbitt and Young, 1984); WL: Ideal feldspar weathering line from a granodiorite source; CIA: Chemical Index of Alteration (Nesbitt and Young, 1982). Typical igneous rock averages from Le Maitre (1976); Grt: Granite; Grd: Granodiorite; Ton: Tonalite; Gabb: Gabbro. Open diamonds: DYC mudstones; Filled diamonds: DYC sandstones; Shaded field: distribution of Permian-early Late Triassic (PF1-PF3) Rakaia terrane sandstones and mudstones (Roser and Korsch, 1999). Also shown are compositions of relevant minerals. The dotted line links the hypothetical igneous source with muscovite, which is a likely end product (after illite) of syn- and post-sedimentation K-metasomatism of clay minerals (Fedo et al., 1995); Dashed line: Field of undifferentiated LeMay Group sandstones (Willan, 2003). 
The major element discriminant functions of Roser and Korsch (1988) provide a method of determining the provenance of both sandstones and mudstones within single successions, with differentiation into four groups (P1-P4), as outlined above. All the DYC samples plotin the $P 3$ field of felsicigneous provenance (Fig. 7a) typical of rocks derived from a silicic crystalline (plutonic-metamorphic) terrainwithalesserintermediateacid volcanic component (Roser and Korsch, 1988).

$\mathrm{SiO}_{2}-\mathrm{Na}_{2} \mathrm{O} / \mathrm{K}_{2} \mathrm{O}$ relations (Roser and Korsch, 1986) are useful for discriminating the tectonic setting of the depositional basin of sandstone-mudstone suites, even though $\mathrm{Na}_{2} \mathrm{O} / \mathrm{K}_{2} \mathrm{O}$ ratios and $\mathrm{SiO}_{2}$ contents can be disturbed by weathering and diagenesis, and the importance of such processes need to be evaluated. The relatively low CIA ratios of the DYC samples and K-metasomatism no greater than in the suites used to define the plot originally suggest its use is appropriate in this case. With one exception, in the $\mathrm{SiO}_{2}-\mathrm{Na}_{2} \mathrm{O} / \mathrm{K}_{2} \mathrm{O}$ plot of figure $5 \mathrm{~b}$ all the $\mathrm{DYC}$ samples plot in the active continental margin (ACM) field, with a marked linear trend and clear differentiation between sandstones and mudstones. This pattern is typical of large ACM accretionary complexes such as the Franciscan and Torlesse terranes (Roser and Korsch, 1986).

A variety of discriminants based on trace elements are also available in the literature. These are mostly based on relatively immobile elements, and can give a clearer indication of provenance and tectonic setting than methods based on the more mobile major elements. The La/Th-Hf plot (Fig. 8a) used by Gu et al. (2002) shows that all DYC sandstones fall in the felsic source field, clustering around the composition of upper continental crust. La/Th ratios in the mudstones are similar to those of the sandstones, but spread towards lower $\mathrm{Hf}$ values. Distribution of the DYC samples and the separation between sandstone and mudstone in the ternary Al-Ti-Hf diagram (Murphy, 2000) is also controlled by $\mathrm{Hf}$ (Fig. 8b). The pattern of higher $\mathrm{Hf}$ in the sandstones reflects the strong geochemical association of this element with $\mathrm{Zr}$, and concentration of zircons in the sandstones.

Equally clear separation between the DYC sandstones and mudstones also occurs on La/Sc-Co/ Th (Fig. 9), Ni-TiO 2 (Fig. 10) and Zr/Sc-Th/Sc (Fig. 11) discriminant plots. Dispersion of the samples on the $\mathrm{La} / \mathrm{Sc}-\mathrm{Co} / \mathrm{Th}$ plot is mainly controlled by the $\mathrm{La} / \mathrm{Sc}$ ratio, as sandstones have higher ratios ( $\mathrm{La} / \mathrm{Sc}$ range 3.14-5.60; average 4.27 \pm 0.96 ) than the mudstones (2.14-2.92, average 2.52 \pm 0.34$)$. However, all samples plot between the compositions of felsic volcanic rocks and granodiorite (Fig. 9). On the $\mathrm{Ni}-\mathrm{TiO}_{2}$ diagram (Fig. 10) of Floyd et al. (1989), the DYC rocks plotclose to the acidic source field. All sandstones plot at lower $\mathrm{Ni}$ and $\mathrm{TiO}_{2}$ concentrations (average
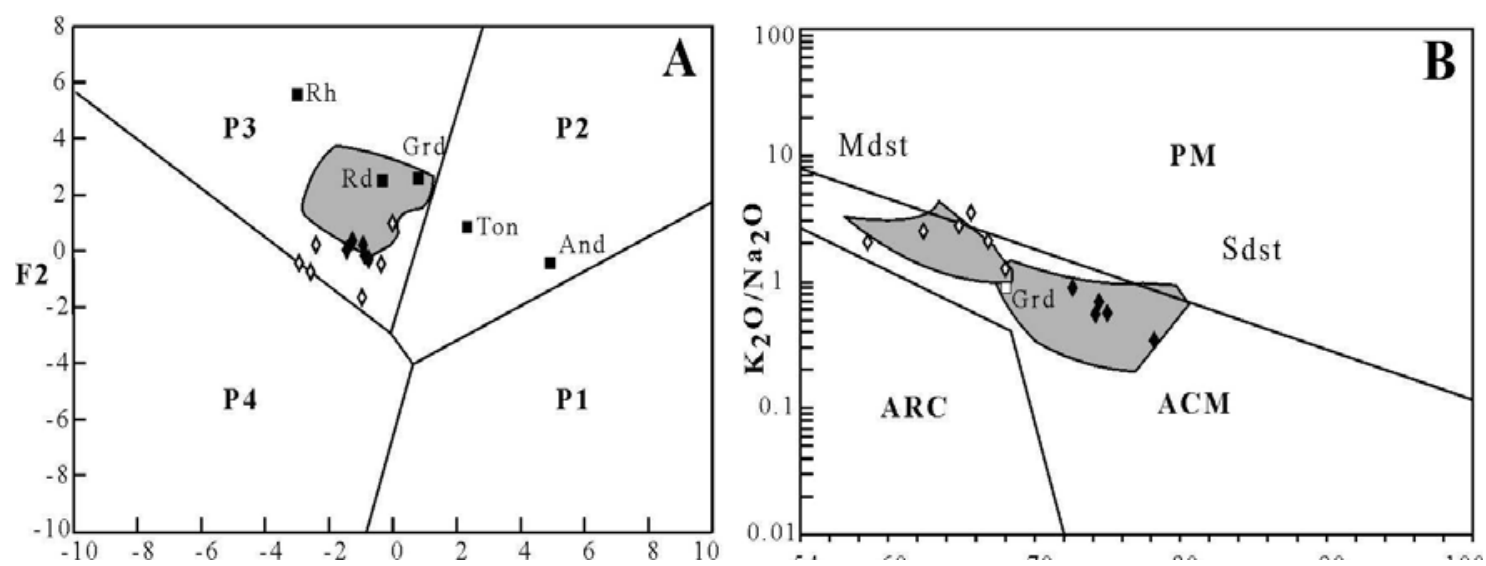

FIG. 7. A. Sedimentary provenance discriminant diagram (Roser and Korsch, 1988). P1: Mafic provenance; P2: Intermediate provenance; P3: Felsic provenance; P4: Quartzose recycled provenance. Typical igneous rock averages from Roser and Korsch (1988), Le Maitre (1976) and Nockolds (1954); Rh: Rhyolite; Rd: Rhyodacite; Grd: Granodiorite; Ton: Tonalite; And: Andesite. Shaded area: Field of Permian-early Late Triassic Rakaia terrane petrofacies (Roser and Korsch, 1999). B. Tectonic setting discriminant diagram (Roser and Korsch, 1986). PM: Passive margin; ACM: Active continental margin; ARC: Oceanic island arc; Shaded areas: Fields for sandstones (Sdst) and mudstones (Mdst) from the Permian-Cretaceous Rakaia and Pahau terranes (Roser and Korsch, 1999); Grd: Sierra Nevada Batholith average granodiorite composition (Bateman and Chappell, 1979). Symbols as in figure 6. 
$12 \pm 4 \mathrm{ppm} \mathrm{Ni}$ and $0.52 \pm 0.06 \mathrm{wt} \% \mathrm{TiO}_{2}$ ) than the mudstones (average of $25 \pm 3 \mathrm{ppm}$ and $0.92 \pm 0.12 \mathrm{wt}$. respectively; Table 1). On the $\mathrm{Zr} / \mathrm{Sc}$ - Th/Sc diagram of McLennan et al. (1993) all the sandstones plot above the $\mathrm{Th} / \mathrm{Sc}$ ratio of upper continental crust field, at higher $\mathrm{Th} / \mathrm{Sc}$ ratios (average $\mathrm{Th} / \mathrm{Sc}=1.4 \pm 0.2$ ) than the mudstones (average Th/Sc=0.9 \pm 0.1 ; Fig. 11). Differentiation between sandstones and mudstones is marked in terms of the $\mathrm{Zr} / \mathrm{Sc}$ ratio, with the sandstones having clearly greater ratios (average $\mathrm{Zr} / \mathrm{Sc}=43 \pm 11$ ) than the mudstones (average $\mathrm{Zr} / \mathrm{Sc}=12 \pm 3$ ), near the composition typical of rhyolite (Fig. 11).

On the major element-based comparative diagram of figure 12 the DYC sandstones plot exclusively in the P3 field (felsic provenance), with less scatter than on the previous discrimination plots.
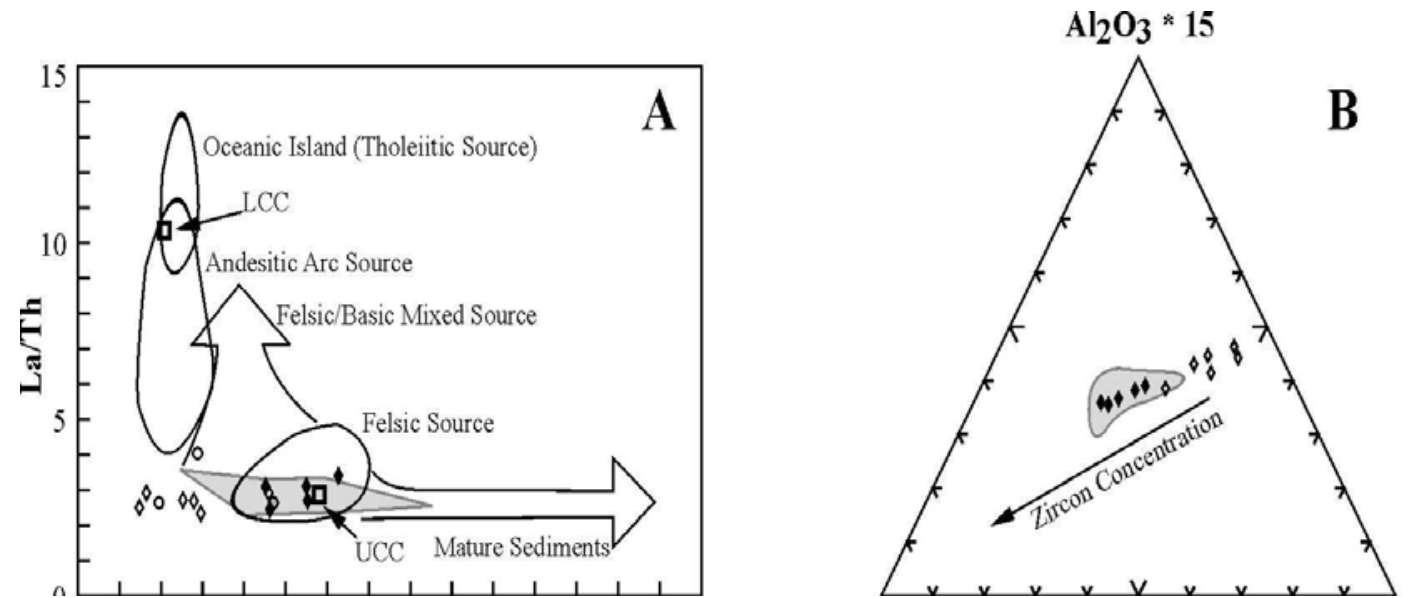

FIG. 8. A. Hf-La/Th sedimentary provenance discriminant diagram (Floyd and Leveridge, 1987); LCC: Lower continental crust; UCC: Upper continental crust; Shaded area: field of 22 PF1-PF3 Rakaia terrane sandstones and 5 mudstones; Open diamonds: DYC mudstones; Filled diamonds: DYC sandstones; Circles: Representative lithic arkoses (open) and feldspathic litharenite (filled) of the LMG (Willan, 2003); B. $\mathrm{Al}_{2} \mathrm{O}_{3}-\mathrm{Hf}-\mathrm{TiO}_{2}$ ternary diagram (Murphy, 2000); Shaded area: Field of 22 sandstones and 5 mudstones from the Permian-Late Triassic Rakaia petrofacies PF1-PF3 (Roser, unpublished data).

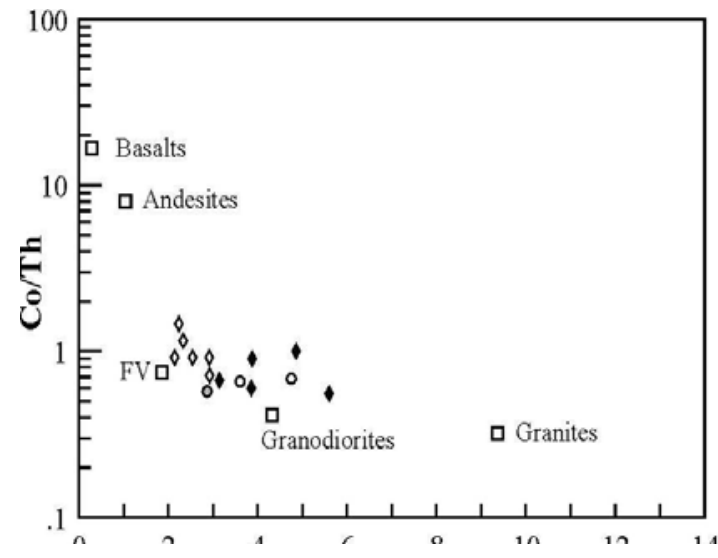

FIG. 9. La/Sc-Co/Th sedimentary provenance discriminant diagram (Floyd and Leveridge, 1987). Average igneous rock types after Condie (1993). FV: Felsic Volcanics. Symbols as in figure $8 a$.

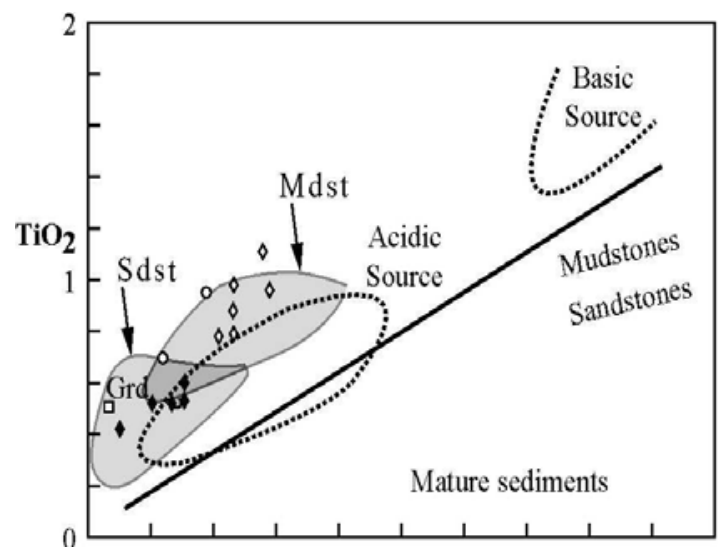

FIG. 10. Ni-TiO 2 sedimentary provenance discriminant diagram (Floyd et al., 1989). Grd (white square): Sierra Nevada Batholith average granodiorite composition (Bateman and Chappell, 1979); Shaded area: Fields for sandstones (Sdst) and mudstones (Mdst) from Rakaia terrane petrofacies PF1-PF3 were defined using analyses drawn from Roser et al. (1995). Symbols as in figure 8a. 


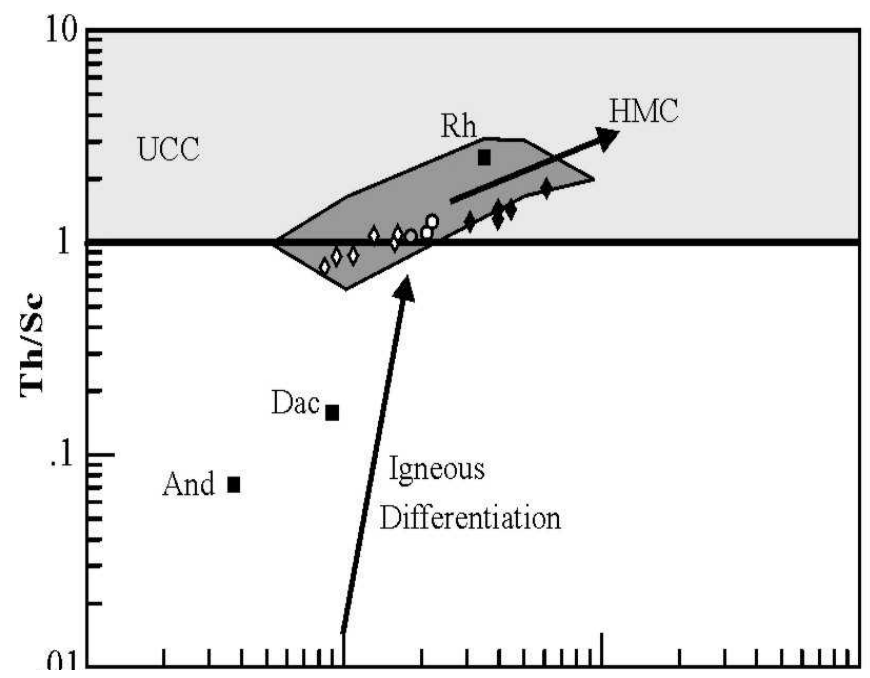

FIG. 11. Zr/Sc-Th/Sc diagram (McLennanetal., 1993). UCC: Upper Continental Crust; HMC: Trend expected for heavy mineral sorting and concentration; Shaded field: distribution of Rakaia terrane PF1-PF3 sandstones and mudstones (Roser and Korsch, 1999); Greyfilled circle: representative LMG sandstone (average of two lithic arkoses and one feldspathic litharenite) from Willan (2003). Other symbols as in figure 8a. Rock averages (black squares): Rh: rhyolite; Dac: dacite; And: andesite.

\section{DISCUSSION}

\section{GRAIN-SIZE EFFECT AND K-METASOMATISM}

The geochemical contrasts between the DYC sandstones and mudstones are directly related to differences in their mineralogy. The higher concentrations of most trace elements in the mudstones are most likely due to the generally higher concentrations of these elements in clays (McLennan et al., 1990). In terms of the CIA parameter, the differences between sandstones and mudstones are an expected grain-size effect, as most muds show more severe weathering histories than do associated sands (McLennan et al., 1990). The higher CIA values of the mudstones and their position on the A$\mathrm{CN}-\mathrm{K}$ plot (Fig. 6, Table 1) reflect their higher clay mineral contents (Nesbitt and Young, 1982), which are the major alteration product after feldspar (Fedo et al., 1995). On this diagram, such a grain-size effect from sorting is expected to produce a distribution similar to that of modern turbidite successions (McLennan etal., 1990), with trends lying parallel or sub-parallel to the feldspar weathering line. However, the DYC samples trend towards illite-muscovite, a feature that is usually indicative of post-depositional K-metasomatism (Fedo et al., 1995). The higher $\mathrm{K}_{2} \mathrm{O}$ abundances in the mudstones (2.77-4.57 wt\%) compared to the sandstones (1.18-2.69 wt\%; Table 1) and their greater dispersion in figures 6 and 7 suggest that Kmetasomatism preferentially affected the mudstones, due to their higher clay mineral content. The two mudstones collected close to the contact between the DYC and the Patagonian Batholith in Contreras Fiord (Fig.1) have the highest $\mathrm{K}_{2} \mathrm{O}$ contents, and thus show greatest displacement on figures 6 and 7 . This suggests that for these samples the DYC K-metasomatism may be related to the Cretaceous intrusion of the Patagonian Batholith.

\section{SEDIMENTARY PROVENANCE AND TECTONIC SETTING OF THE DUQUE DE YORK COMPLEX}

The framework composition of the DYC sandstones points towards a volcanic arc source that was relatively proximal to the depositional basin, as suggested by the immature textural characteristics of the detrital grains. Their position on the QFL diagram (Fig. 4) implies derivation from an eroded arc in which the plutonic roots had been exposed by erosion (Dickinson et al., 1983). CIA values of the DYC samples range from 58 to 71 (Fig. 6; Table 1). Although these are lower than the CIA ratios of average mudstones (range 70-75; Taylor and McLennan, 1985), such values indicate moderate to intense chemical weathering in the source (Fedo et al., 1995). Furthermore, the linear trend in A-CN-K space and separation of sandstones and mudstones (Fig. 6) suggests active source uplift, with dissection under non-steady state conditions (Nesbitt et al., 1997).

Average major and trace element abundances in the DYC sandstones (Table 1) can be compared with 
the characteristic elemental concentrations of sandstones from the P1-P4 provenance groups as calculated by Lacassie et al. (2004). For most of the major $\left(\mathrm{SiO}_{2}, \mathrm{TiO}_{2}, \mathrm{Al}_{2} \mathrm{O}_{3}, \mathrm{Na}_{2} \mathrm{O}, \mathrm{CaO}, \mathrm{Fe}_{2} \mathrm{O}_{3} \mathrm{t}\right.$ and $\mathrm{MgO})$ and the high field strength trace elements ( $\mathrm{Y}$, $\mathrm{Nb}$, Th and Sc), average DYC concentrations are consistent with sandstones of the felsic P3 group. Similarly, in terms of geochemical parameters that reflect provenance type (Table 3), average DYC sandstone compositions coincide with that characteristic of the P3 group, which is associated with sources of felsic composition (Roser and Korsch, 1988). Distribution of the DYC rocks on the major and trace element-based diagrams (Figs. 6-11) further suggest that they were derived from felsic igneous rocks with an average granodioritic composition.

Major element-based discrimination and comparative diagrams also indicate that the DYC was deposited in an active tectonic setting. On most of these diagrams the DYC tectonic regime corresponds to an active continental margin (Figs. 7 and 12). This Andean-type setting for the depositional basin of the DYC rocks is also suggested by the similar plot positions of the DYC samples and average granodiorite from the Sierra Nevada Batholith (Figs. 7 b and 10), which represents a continental subductionrelated magmatic arc (Manniar and Piccoli, 1989).

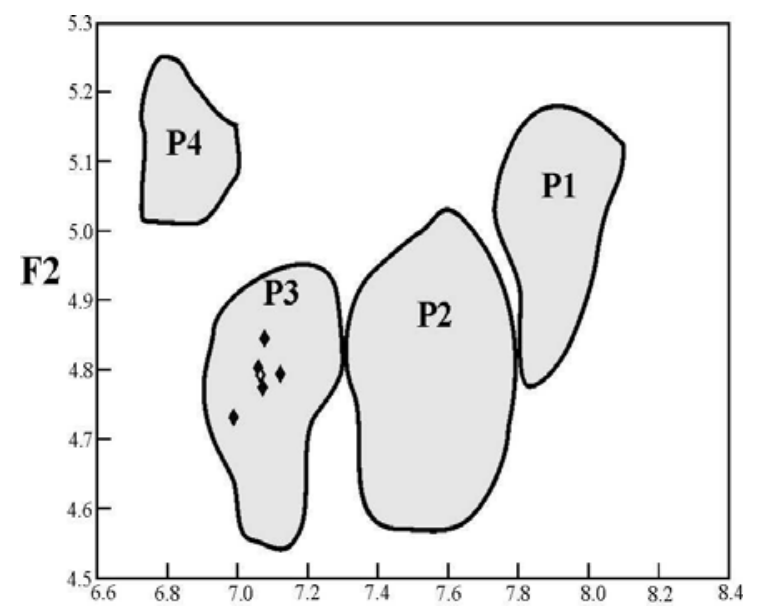

FIG. 12. F1 versus F2 major element-based comparative diagram after the discriminant function analysis of the dataset of table 2. Unstandarized coefficients of the F1 and F2 discriminant functions are indicated in the table 4. Provenance types after Roser and Korsch (1988). P1: Mafic provenance; P2: Intermediate provenance; P3: Felsic provenance; P4: Quartzose recycled provenance; White diamond: DYC sandstone average. Other symbols as in figure 6 .
TABLE 4. UNSTANDARIZED COEFFICIENTS OF THE F1 AND F2 DISCRIMINANT FUNCTIONS.

\begin{tabular}{|ccc|}
\hline Oxide & F1 & F2 \\
\hline $\mathrm{SiO}_{2}$ & 0,06 & 0,05 \\
$\mathrm{TiO}_{2}$ & 0,31 & 0,56 \\
$\mathrm{Al}_{2} \mathrm{O}_{3}$ & 0,11 & 0,03 \\
$\mathrm{Fe}_{2} \mathrm{O}_{3} \mathrm{t}$ & 0,09 & 0,02 \\
$\mathrm{MnO}$ & 0,93 & 0,37 \\
$\mathrm{MgO}$ & 0,03 & 0,12 \\
$\mathrm{CaO}$ & 0,09 & 0,03 \\
$\mathrm{Na}$ & $-0,06$ \\
$\mathrm{~K}_{2} \mathrm{O}$ & 0,11 & 0,02 \\
$\mathrm{P}_{2} \mathrm{O}_{5}$ & 0,01 & 0,73 \\
\hline
\end{tabular}

\section{OTHER PALEOZOIC-CENOZOIC SUBDUCTION COMPLEXES OF THE PANTHALASSIC GONDWANA MARGIN}

\section{THE TORLESSE SUPERTERRANE}

The Torlesse Superterrane crops out extensively in the South and North Islands of New Zealand. It consists of well-bedded quartzofeldspathic sandstones and mudstones, and in the South Island has been subdivided into the Rakaia terrane (PermianLate Triassic), the Eask Head melange terrane, and the Pahau terrane (Late Jurassic-Early Cretaceous; Fig. 13). Based on recognized fossil zones, MacKinnon (1983) divided the South Island Rakaia terrane into four age-related petrofacies (PF): PF1 (Permian), PF2 (Middle Triassic), PF3 (?late-Middle-early-Late Triassic), and PF4 (Late Triassic). The Pahau terrane consists of a single petrofacies, PF5 (Late JurassicEarly Cretaceous). Based on modal petrographic data, MacKinnon (1983) proposed that the bulk of the Torlesse was derived from an active continental margin volcano-plutonic arc and was deposited at a trench or transform boundary at the Gondwana margin, and subsequently underwent strike-slip translation subparallel to the margin prior to collision. Whole rock geochemical signatures of Torlesse petrofacies record progressive chemical evolution of a major accretionary wedge, derived from a relatively unweathered source averaging near granodiorite composition (Mortimer, 1995; Roser and Korsch, 1999). The chemical data largely support MacKinnon's petrographic model and indicate a relatively uniform chemistry in PF1-PF3 (Roser and Korsch, 1999), 
consistent with the small contrasts in detrital modal composition in those petrofacies. Roser and Korsch (1999) considered that chemical changes between P3 and P4 were consistent with the onset of recycling, as proposed by MacKinnon (1983). Geochemical signatures in Pahau terrane rocks reflected extensive recycling of Rakaia and lesser inboard volcanogenic terranes (Roser and Korsch, 1999). Recent work by Wandres et al. (2004a) on the petrography and geochemistry of sandstone clasts in Pahau conglomerates confirm recycling of Permian to early Late Triassic Rakaia rocks, and is further supported by their detrital zircon age data.

\section{THE LEMAY GROUP}

The LeMay Group (LMG) of Alexander Island is athick, unfossiliferous succession of variably deformed and metamorphosed turbiditic sandstones and mudstones, and igneous rocks, on the west coast of Antarctic Peninsula(Tranter, 1991; Fig. 13). The oldest LMG outcrops contain radiolarian cherts of Late Triassic age (Holdsworth and Nell, 1992). Early Jurassic shelly fauna (204-195 Ma) are also present at two localities in the Lully Foothills accreted volcanic-island succession (Thompson and Tranter, 1986; cited in Willan, 2003). Burn (1984; cited in Willan, 2003) subdivided the LMG into four lithological associations: conglomeratesandstone-mudstone, sandstone-mudstone, basalttuff and basalt-chert. The basaltic lavas of the latter association have an N-MORB chemistry, whereas basalts of the basalt-tuff association exhibit E-MORB, N-MORB and tholeiitic chemistry (Doubleday et al., 1994), representing an accreted oceanic-island succession (Burn, 1984; Garret and Storey, 1987; Doubleday and Tranter, 1992: all cited in Willan, 2003). The LMG sedimentary facies are interpreted as turbidity flows, and modal analysis indicates derivation from a magmatic arc source (Tranter, 1991). However, according to the petrographic study of Willan (2003) the LMG represents two different provenances: a deeply eroded continental margin and a proximal mafic arc source, the latter being the source of the 'volcanolithic' sandstones of the LMG. This mixed provenance is supported by the chemical data for these rocks, which indicates that mostLMG sandstones were derived from a source of average granodioritic composition, whereas the precursor of the volcanolithic population was of more mafic andesitic composition (Willan, 2003). Both the petrographic and geochemical compositions of the LMG sedimentary rocks point towards an active margin setting (Tranter, 1991; Willan, 2003). After deposition, the LMG succession was subjected to deformation within the upper parts of a subduction accretionary complex (Tranter, 1991).

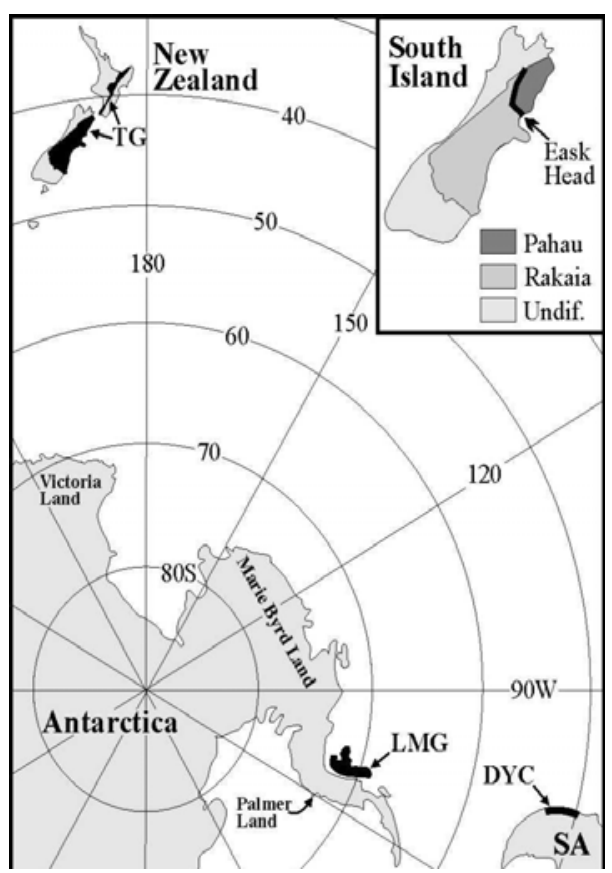

FIG. 13. South America(SA)-Antarctica-New Zealand map showing location of terranes described in the text. TG: Torlesse Group; LMG: LeMay Group; DYC: Duque de York Complex. Redrawn from Wandres et al. (2004b). Inset: Distribution of terranes of the Torlesse Group. The offshore extention of the Pahau terrane is not indicated; Undif: Undifferentiated New Zealand's suites and tectonostratigraphic terranes of the Western Province (Lower Paleozoic metasedimentary rocks cut by Devonian, Carboniferous and Early Cretaceous granitoids with minor volcanic and metamorphic rocks of Cambrian age), Median Tectonic Zone (suites of Carboniferous to Early Cretaceous subduction related calc-alkaline plutons with subordinate volcanic and sedimentary rocks) and Eastern Province (arc, forearc and accretionary complex rocks that relate to Permian to Cretaceous plate convergence; Wandres et al., 2004b).

\section{COMPARISON BETWEEN THE DUQUE DE YORK COMPLEX, THE RAKAIA TERRANE AND THE LEMAY GROUP}

Available modal, geochemical, and geochronological data provide a three-fold basis for comparison between the DYC, Rakaia terrane (the most relevant of the Torlesse terranes), and the LeMay Group (Fig. 13). QFL relations (Fig. 4) show that modal compositions of the DYC sandstones and 
Permian-Triassic PF1-PF3 petrofacies Rakaia counterparts are very similar, with all falling in the dissected arc field. The DYC sandstones also plot within or close to the lower boundary of the LMG sandstone field defined by Tranter (1991). All DYC data also fall within the broader LMG sandstone field defined by Willan (2003), although none show the more lithic transitional arc compositions of the volcanogenic members of that group.

CIA values of the DYC sandstones (58-64) are greater than those of Rakaia sandstones (53-54). However, CIA values of the DYC mudstones (range of 63-71) are similar to those of the Rakaia mudstones (generally <70; Table 1; Roser and Korsch, 1999), and these will most accurately reflect intensity of weathering of their sources. Both the DYC and Rakaia thus exhibit degree of weathering comparable with modern active margin sediments (Roser and Korsch, 1999). Maximum CIA in the LMG is also similar (Fig. 6). Distributions of DYC, Rakaia and LMG turbidites in A-CN-K space are broadly coincident (Fig. 6), although inclination of their respective trends differs slightly, suggesting varying degrees of K-metasomatism for these three successions: relatively low for the LMG, intermediate for the Rakaia and high for the DYC. All three trends, however, originate from primary source compositions in the range tonalite-granodiorite.

For the major element provenance discriminants (Fig. 7a), DYC sandstones plot on the edge of the Rakaia field at lower F2 values, and most DYC mudstones plot lower still, down to the P3-P4 join. These contrasts may reflect the slightly higher CIA ratios in DYC sandstones, and more marked $\mathrm{K}$ metasomatism in the mudstones. $\mathrm{SiO}_{2}-\mathrm{K}_{2} \mathrm{O} / \mathrm{Na}_{2} \mathrm{O}$ distributions of DYC and Rakaia sandstones and mudstones are very similar, with each lithotype having almost perfect overlap (Fig. 7b). Equally good matches are evident on trace element diagrams involving $\mathrm{Hf}$ (Fig. 8), although the DYC mudstones spread to lower values, and on the $\mathrm{Ni}^{-\mathrm{TiO}_{2}}$ diagram (Fig. 10), where the distributions of DYC sandstones and mudstones coincide with their Rakaia counterparts. In the $\mathrm{Zr} / \mathrm{Sc}$-Th/Sc plot (Fig. 11) the trend of the DYC samples lies within the field of Rakaia sandstones and mudstones (Roser and Korsch, 1999). However, the DYC sandstones have higher average $\mathrm{Zr} / \mathrm{Sc}$ ratio $(\mathrm{Zr} /$ $\mathrm{Sc}=43$ ) than PF1-PF3 Rakaia sandstones (average $\mathrm{Zr} / \mathrm{Sc}=22$; Roser and Korsch, 1999). This is indicative of greater zircon concentration in the DYC sandstones, possibly due to longer transport, more intense weathering of the sands, or some degree of recycling.
Three representative LMG sandstones (two lithic arkoses and one feldspathic litharenite) from Willan (2003) have also been plotted on the trace elementbased discriminant diagrams (Figs. 8a, 9, 10 and 11). With the exception of figure $8 a$, there is general coincidence between the distributions of the LMG and DYC sandstones. The main difference between the LMG and DYC sandstones in figure 8a is their respective $\mathrm{Hf}$ and $\mathrm{Zr}$ contents. DYC sandstones have systematically higher $\mathrm{Hf}$ and $\mathrm{Zr}$ abundances (average 5.3 \pm 0.7 ppm and 291 \pm 26 ppm, respectively; Table 1) than the representative LMG samples $(2.1 \pm 0.9$ ppm and 189 \pm 17 ppm, respectively; Willan, 2003). This is again indicative of a higher degree of zircon concentration in the DYC. This is also evident in the $\mathrm{Zr} /$ Sc-Th/Sc diagram (Fig. 11), with higher Zr/Sc ratios in the DYC sandstones than in LMG. The DYC sandstones have an average $\mathrm{Zr} / \mathrm{Sc}$ ratio of 43 , more than double that of LMG counterparts (average $\mathrm{Zr} / \mathrm{Sc}$ = 20; Willan, 2003). However, the trends of the two successions are identical.

Chondrite-normalized REE patterns of the DYC rocks and the chondrite-normalized REE ranges of the Rakaia and LMG suites are also similar (Fig. 14). However, the DYC rocks tend to have less negative Eu-anomalies than Rakaia sandstones and mudstones, which suggests a lower degree of intracrustal plagioclase fractionation (McLennan et al., 1990) for the DYC igneous source relative to the igneous precursors of the Rakaia turbidites.

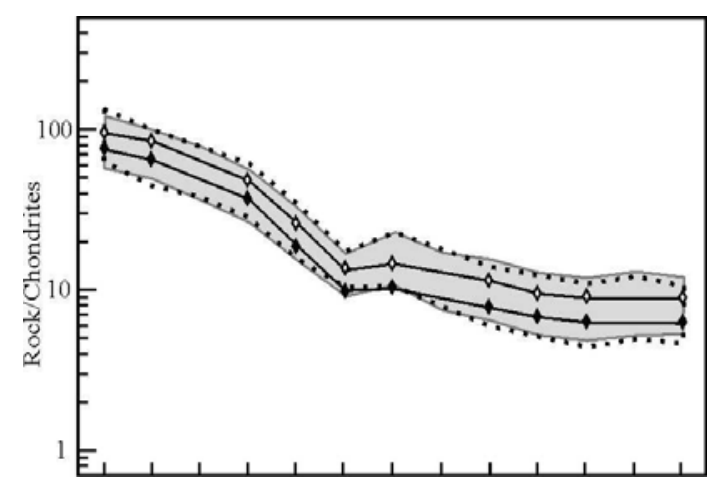

FIG. 14. Comparison of chondrite-normalized REE patterns for DYC, Rakaia and LMG turbidites. Shaded area: range of compositions in 22 sandstones and 5 mudstones from PF1-PF3 of the Rakaia terrane (Roser, unpublished data); Dotted lines: range in LMG sandstones (Willan, 2003). Chondrite normalizing factors from Taylor and McLennan (1985); Filled diamond: average DYC sandstone $(n=5)$; Open diamond: average DYC mudstone $(n=6)$. 
Detrital zircon U-Pb SHRIMP age determinations in DYC metasandstones from the Madre de Dios and Diego de Almagro archipelagos reveal three different age populations of zircons of igneous derivation. These are a prominent late Early Permian population (270-290 Ma), and two minor populations of Late Proterozoic and Early Paleozoic ages (Hervé et al., 1999a; Hervé et al., 2003). Ireland (1992) reported a prominent late Early Permian $(260 \pm 8 \mathrm{Ma})$ detrital zircon age population from the Rakaia terrane, along with two minor populations of Late Proterozoic (ca. $1100 \mathrm{Ma}$ ) and Early Paleozoic (500-600 Ma) age. Detrital zircons in the eastern (Triassic) LMG show similar age patterns, with Permian, Cambrian, Ordovician and Carboniferous ages (265, 530, 470 and $350 \mathrm{Ma}$; Millar et al., 2001). Similarly, detrital zircon U-Pb age data from Wandres et al. (2004b) show main Permian peaks at 270 and 265 Ma for two Rakaia sandstones from Kurow Hill and Balmacaan Stream, respectively. Both sandstones also contain a prominent Early Paleozoic population with peaks at 510 and $495 \mathrm{Ma}$, respectively (Wandres et al., 2004b). Direct comparison of cumulative probability curves for sandstones from the DYC and the Rakaia terrane shows striking coincidence of their main Permian peaks, and, to a lesser extent, the minor age populations, in particular the Early Paleozoic one (Fig. 15).
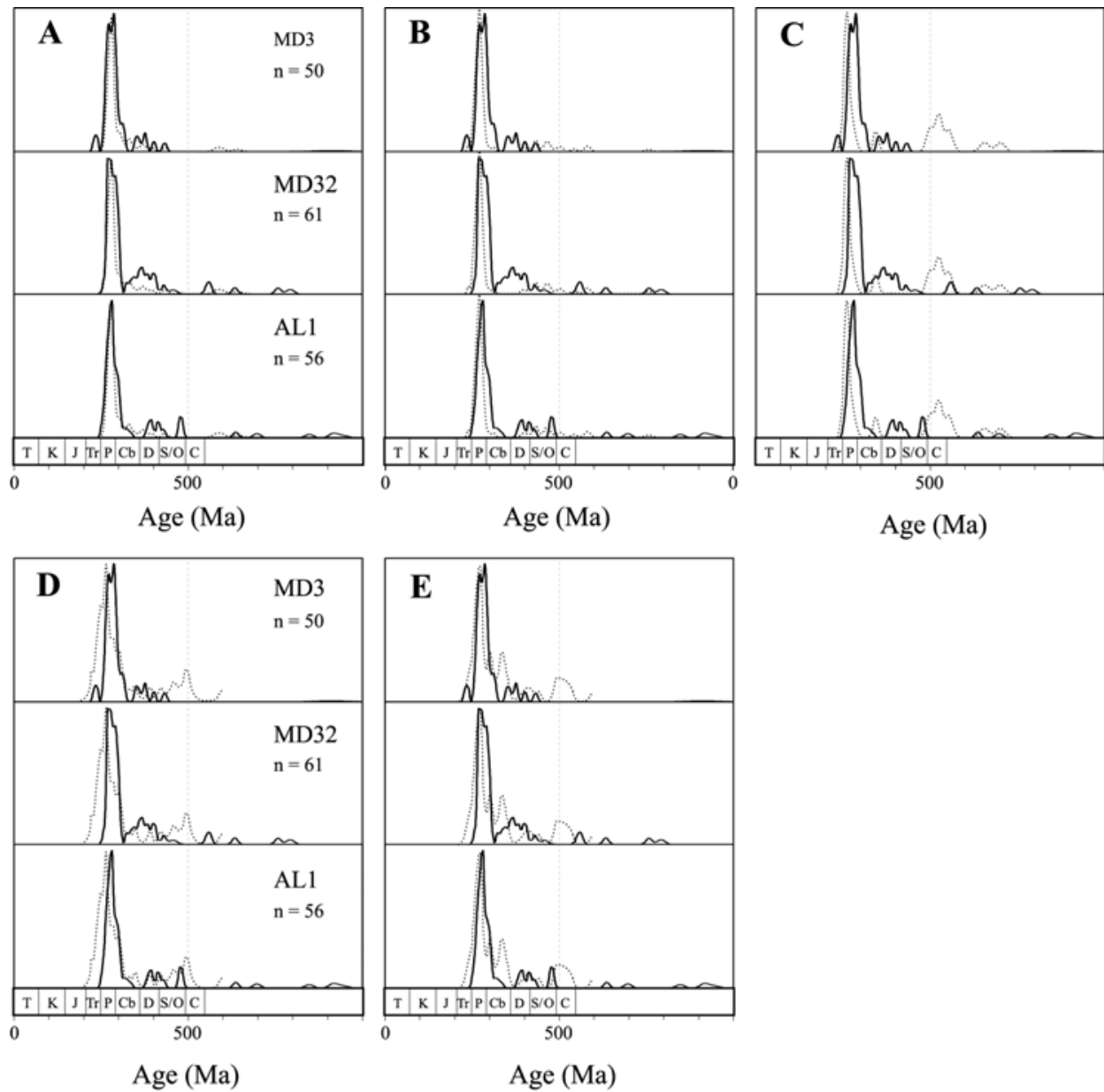

Age (Ma)

Age (Ma)

FIG. 15. Comparison of detrital zircon age cumulative probability curves for three DYC sandstones (MD3, MD32, AL1; solid lines) and five Rakaia sandstones (dashed lines). The vertical scales of the cumulative probability curves have been adjusted to match the heights of the major peaks. $\mathbf{n}$ : Number of analyzed detrital zircons in the DYC samples (Hervé et al., 2003). A:Rakaia sandstone, Pareora River, detrital zircon n=72 (Pickard et al., 2000); B: Rakaia sandstone, Kakahu Inlier, n=72 (Pickard et al., 2000); C: Rakaia greywacke, Lake Aviemore, $\mathrm{n}=20$ (Ireland, 1992); D: Rakaia sandstone, Balmacaan Stream, $\mathrm{n}=64$ (Wandres et al., 2004b). E: Rakaia sandstone, Kurow Hill, $\mathrm{n}=60$ (Wandres et al., 2004b). 


\section{PALEOGEOGRAPHIC INFERENCES}

There is no evidence of other accreted terranes at the Gondwana margin or a possible igneous source of Early Paleozoic detrital zircons at latitudes lower than that of the Madre de Dios archipelago (Rapalini et al., 2001; Cawood et al., 2002). In contrast, there is evidence of terrane accretion at the Gondwana margin at latitudes lower than the Madre de Dios archipelago, involving the portion of the Gondwana margin constituted by South America, in continuity with Western Antarctica and New Zealand (Adams and Kelley, 1998; Hervé etal., 2002; Vaughan and Storey, 2000; Vaughan, 2003). Consequently, a possible paleotectonic scenario is first accretion of a Denaro Complex-Tarlton Limestone seamount at the Antarctica-Australian portion of the Gondwana margin, followed by dextral translation parallel to the margin. Potential igneous sources of late Early Permian and Early Proterozoic zircons crop out in that margin in east Australia, New Zealand and West Antarctica (Cawood et al., 2002).

The combined geochronological, geochemical and isotopic data of Rakaiaigneous clasts indicates that this succession was derived from a volcanic/plutonic continental arc that experienced continuous magmatism into the early Middle Triassic, and had Cambrian and Carboniferous plutonic and volcanic rocks exposed at the time of erosion (Wandres et al., 2004b).

Adams and Kelley (1998) favoured a New England Orogen source for the Torlesse terranes due absence of suitable igneous sources in New Zealand, Victoria Land or Tasmania. However, Roser and Korsch (1999) pointed out petrographic and geochemical difficulties for derivation of the Rakaia compositions from the New England Orogen. Wandres et al. (2004b) also disregarded a New England source as it lacks the Cambrian igneous rocks required to account for the presence of the older (Cambrian) cobblesized igneous clasts in Rakaia conglomerates. According to Wandres et al. (2004b), the geochemical and isotopic characteristics of the Rakaia Cambrian igneous clasts correlates well with basement rocks of West Antarctica (Ross Province of Marie Byrd Land), which they favoured as the Cambrian protosource for the Rakaia detritus. They also ascribed the Cambrian detrital zircon age peaks in Rakaia sandstones from their and other studies to detrital contribution from Amundsen/ Ross Province basement.

The Ross Province contains also abundant evidence for plutonism between 377 and $330 \mathrm{Ma}$, and formation of a Permian arc between 290 and 240 Ma(Pankhurstetal., 1998; Mukasa and Dalziel, 2000). There is also evidence for Permian S-Type granites in northeast Palmer Land and southern Graham Land, which contain 470 Ma inherited sources (Millar et al., 2002). In particular, Middle to Late Triassic orthogneisses in western Palmer Land contain a similar zircon assemblage (Millar et al., 2001) to that of the eastern LMG sandstones (Willan, 2003).

According to Wandres et al. (2004b) the geochemistry of igneous clasts from the Rakaia conglomerates correlates broadly with that of the Median Tectonic Zone/Amundsen Province Igneous Belt (MAIB; Wandres et al. 2004a) and its older inboard provinces. The belt also contains plutonic and volcanic rocks of ages appropriate to explain the igneous clast populations sampled in the Rakaia conglomerates and to account for the detrital zircon age signatures in Rakaia sandstones (Wandres et al., 2004b). Therefore, these authors postulated that the Amundsen and Ross Provinces were likely sources for the Permo-Triassic, Carboniferous and Cambrian igneous clasts, respectively. The Permian detrital zircon age peaks in Rakaiasandstones suggest that granitoids from the Kohler Range were a major source for the Triassic sediments (Wandres et al., 2004b).

The above petrographic, geochemical and geochronological similarities between the DYC, Rakaia and LMG successions show that they were derived from igneous sources of similar compositions, and suggest that they were deposited along the same active continental margin. This margin was probably located along the Antarctic sector of the Gondwana margin (including Palmer Land, Graham Land and Marie Byrd Land), as favoured for the sources of Rakaia and LMG by Willan (2003) and Wandres et al. (2004b), respectively.

\section{CONCLUSIONS}

DYC sandstones and mudstones show systematic grain-size-related geochemical contrasts which reflect higher content of clay minerals in the mudstones, and higher proportions of quartz, plagioclase feldspar, and 
zircon in the sandstones. Textural characteristics, framework compositions and whole-rock geochemical data of the DYC rocks point towards a relatively proximal volcanic arc source of granodioritic average composition, the plutonic roots of which had been exposed by erosion. The arc was likely located at an active continental margin. CIA ratios suggest the source was only moderately weathered, and that the sediments were affected by post-depositional K-metasomatism.

Significant petrographic, geochemical and geochronological similarities exist between the DYC turbidites and counterparts in the Rakaia terrane and the LMG. These similarities point towards igneous sources of similar composition for the three successions, and suggest that they were contemporary deposited along the same active continental margin. This margin was probably located along the Antarctic sector of the Panthalassan Gondwana margin, as favoured by the studies of Willan (2003) for the source area of the LMG, and of Wandres et al. (2004b) and Cawood (2002) for the source area of the Rakaia terrane.

\section{ACKNOWLEDGEMENTS}

This research was supported by CONICYT under the Doctoral Fondecyt Project No. 2010010 to J.P. Lacassie and the Fondecyt Project No. 1010412 to F. Hervé. Our thanks to R. Fernández (INACH), to the speleologists J.M. James and A. Warild (Australia), to J. Muñoz (SERNAGEOMIN) and to the members of CONAF-Puerto Edén, Guarello Mine and Última Patagonia 2000 Expedition, for their support during the field campaigns. We are indebted to H. Campbell (Institute of Geological and Nuclear Sciences, New
Zealand) and F. Aceñolaza (Universidad Nacional de Tucumán, Argentina) for identifying the fossil assemblages. This manuscript was greatly improved by the very helpful critical reviews of C. Auggustsson (University of Münster, Germany), C. Muruaga (Universidad Nacional de Tucumán, Argentina), L. Spalletti (Universidad Nacional de La Plata, Argentina), G.M. Young (University of Western Ontario, Canada) and H. Bahlburg (Universität Müster, Germany).

\section{REFERENCES}

Adams, C.J.; Kelley, S. 1998. Provenance of PermianTriassic and Ordovician metagraywacke terranes in New Zealand: evidence from ${ }^{40} \mathrm{Ar} /{ }^{39} \mathrm{Ar}$ dating of detrital micas. Geological Society of America Bulletin 110: 422-432.

Bateman, P.C.; Chappell, B.W. 1979. Crystallization, fractionation and solidification of Toulumne Intrusive Series, Yosemite National park, California. Geological Society of America Bulletin 90: 465-482.

Bhatia, M.R. 1985. Composition and classification of Paleozoic flysch mudrocks of eastern Australia: implications in provenance and tectonic setting interpretation. Sedimentary Geology 41: 249-268.

Bruce, R.M.; Nelson, E.P.; Weaver, S.G.; Lux, D.R. 1991. Temporal and spatial variations in the southern Patagonian batholith; Constraints on magmatic arc development. In Andean Magmatism and Its Tectonic Setting (Harmon, R.S.; Rapela, C.W.; editors). The Geological Society of America, Special Paper 265: 112.

Burn, R.W. 1984. The geology of the LeMay Group, Alexander Island. Cambridge, U.K. British Antarctic Survey, Scientific Reports 109: 65 p.
Cawood, P.; Landis, C.; Nemchin, A.; Hada, S. 2002. Permian fragmentation, accretion and subsequent translation of a low-latitude Tethyan seamount to the high-latitude east Gondwana margin: evidence from detrital zircon age data. Geological Magazine 139 (2): 131-144.

Condie, K.C. 1993. Chemical composition and evolution of the upper continental crust: Contrasting results from surface samples and shales. Chemical Geology 104: p. 1-37.

Dickinson, W.R.; Beard, L.S.; Brakenridge, G.R.; Erjavec, J.L.; Ferguson, R.C.; Inman, K.F.; Knepp, R.A.; Lindberg, F.A.; Ryberg, P.T. 1983. Provenance of North American Phanerozoic sandstones in relation to tectonic setting. Geological Society of America Bulletin 94: 222-235.

Douglass, R.C.; Nestell, M.K. 1976. Late Paleozoic foraminifera from southern Chile. U.S. Geological Survey, Special Paper 858: 49 p.

Doubleday, P.A.; Leat, P.T.; Alabaster, T.; Nell, P.A.R.; Tranter, T.H. 1994. Allochthonous oceanic basalts within the Mesozoic accretionary complex of Alexander Island, Antarctica: remnants of proto-Pacific oceanic 
crust. Journal of the Geological Society 151 (1): 6578.

Doubleday, P.A.; Tranter, T.H. 1992. Modes of formation and accretion of oceanic material on the Mesozoic forearc of central and southern Alexander Island: a summary. In Recent Progress in Antarctic Earth Science (Yoshida, Y.; Kaminuma, K.; Shiraishi, K.; editors). Tokyo, Terra Scientific Publishing Company: 377-382.

Faúndez, V.; Hervé, F.; Lacassie, J. P. 2002. Provenance and depositional setting of pre-Late Jurassic turbidite complexes in Patagonia, Chile. New Zealand Journal of Geology and Geophysics 45 (4): 411-425.

Fedo, C. M.; Nesbitt, H. W.; Young, G. M. 1995. Unravelling the effects of potassium metasomatism in sedimentary rocks and paleosols, with implications for paleoweathering conditions and provenance. Geology 23 921-924.

Floyd, P.A.; Leveridge, B.E. 1987. Tectonic environment of the Devonian Gramscatho basin, south Cornwall: framework mode and geochemical evidence from turbiditic sandstones. Journal of the Geological Society, London 144: 531-542.

Floyd, P.A.; Winchester, J. A.; Park, R.G. 1989 Geochemistry and tectonic setting of Lewisian clastic metasediments from the early Proterozoic Loch Maree Group of Gairloch, N.W. Scotland. Precambrian Research 45: 203-214.

Forsythe, R.D.; Dalziel, I.W.D.; Mpodozis, C.; Hall, B. Barrientos, S. 1981. Geologic studies in the outer Chilean fiords, R/V Hero cruise 79-5. Antarctic Journal of the United States 15 (5):109-111.

Forsythe, R.D.; Mpodozis, C. 1983. Geología del Basamento pre-Jurásico Superior en el Archipiélago Madre de Dios, Magallanes, Chile. Servicio Nacional de Geología y Minería, Boletín 39: 63 p.

Friedman, G.M.; Sanders, J.E. 1978. Principles of Sedimentology. John Wiley: 792 p. New York.

Frost, C.D.; Coombs, D.S. 1989. Nd isotope character of New Zealand sediments: implications for terrane concepts and crustal evolution. American Journal of Science 289: 744-770.

Garret, S.W.; Storey, B.C. 1987. Lithospheric extension in the Antarctic Peninsula during Cenozoic subduction. In Continental Extensional tectonics (Coward, M.P.; Dewey, J.F.; Hancock, P.L.; editors). Geological Society of London, Special Publication 28: 419-431.

Gill, J.B.; Hiscott, R.N.; Vidal, P. 1994. Turbidite geochemistry and evolution of the Izu-Bonin arc and continents. Lithos 33: 135-168

Gu, X.X.; Liu, J.M.; Zheng, M.H.; Tang, J.X.; Qi, L. 2002. Provenance and tectonic setting of the Proterozoic turbidites in Hunan, South China: Geochemical Evidence. Journal of Sedimentary Research 72 (3): 393-407.

Hervé, F.; Fanning, M.; Bradshaw, J.; Bradshaw, M.; Lacassie, J.P. 1999a. Late Permian SHRIMP U-Pb detrital zircon ages constrain the age of accretion of oceanic basalts to the Gondwana margin at the Madre de Dios archipelago, southern Chile. In International Symposium on Andean Geodynamics, 4, Extended Abstracts: 327-328. Göttingen.

Hervé, F.; Prior, D.; López, G.; Ramos, V.; Rapalini, A.; Thompson, S.; Lacassie, J. P.; Fanning, M. 1999b. Mezosoic blueschists from Diego de Almagro, southern Chile. In South American Symposium on Isotope Geology, 2, Actas 2: 318-321.

Hervé, F.; Bradshaw, J.; Pankhurst, R.J. 2002. Low grade Early Permian (?) metasedimentary complexes at the western entrance of the Strait of Magellan. In International Symposium on Andean Geodynamics 5, Expanded Abstracts. Toulouse.

Hervé, F.; Fanning, C.M.; Pankhurst, R.J. 2003. Detrital zircon age patterns and provenance of the metamorphic complexes of southern Chile. Journal of South American Earth Sciences 16: 107-123.

Holdsworth, B.K.; Nell, P.A.R. 1992. Mesozoic radiolarian faunas from the Antarctic Peninsula: age, tectonic and paleogeographic significance. Journal of the Geological Society of London 149: 1003-1020.

Ingersoll, R.V.; Bullard, T.F.; Ford, R.D.; Grimm, J.P.; Pickle, J.D. 1984. The effect of grain size on detrital modes: A test of the Gazzi-Dickinson point counting method. Journal of Sedimentology Petrology 54: 103116.

Ireland, T.R. 1992. Crustal evolution of New Zealand: evidence from age distribution of detrital zircons in Western Province paragneisses and Torlesse graywacke. Geochimica et Cosmochimica Acta 56: 911-920.

Lacassie, J.P. 2003. Estudio de la proveniencia sedimentaria de los complejos metamórficos de los Andes Patagónicos ( $46^{\circ}-51^{\circ}$ Lat.S) mediante la aplicación de redes neuronales e isótopos estables. Doctoral Thesis (Unpublished), Universidad de Chile, Departamento de Geología: 204 p.

Lacassie, J.P.; Ruiz-Del-Solar, J.; Hervé, F. 2004. Discovering geochemical patterns using selforganizing neural networks: a new perspective for sedimentary provenance analysis. Sedimentary Geology 165: 175-191.

Le Maitre, R.W. 1976. The chemical variability of some common igneous rocks. Journal of Petrology 17: p. 589-637.

Le Maitre, R. W. 1982. Numerical Petrology: statistical interpretation of geochemical data. Elsevier Science, Developments in Petrology 8: $281 \mathrm{p}$.

Ling, H.Y.; Forsythe, R.D.; Douglass, C.R. 1985. Late Paleozoic microfaunas from southernmost Chile and their relation to Gondwanaland forearc development. Geology 13: 357 - 360.

Manniar, P.D.; Piccoli, P.M. 1989. Tectonic discrimination of granitoids. Geological Society of America Bulletin 101: 635-643.

McCann, T. 1991. Petrological and geochemical determination of provenance in the southern Welsh 
Basin. In Developments in Sedimentary Provenance Studies (Morton, A. C.; Todd, S.P.; Haughton, P.D. W.; editors). Geological Society, Special Publication 57: 215-230.

McDaniel, D.K.; Hemming, S.R.; McLennan, S.M.; Hanson, G.N. 1994. Petrographic, geochemical, and isotopic constrains of the provenance of the Early Proterozoic Chelmsford Formation, Sudbury basin, Ontario. Journal of Sedimentary Research A64 (2): 363-372.

MacKinnon, T.C. 1983. Origin of the Torlesse terrane and coeval rocks, South Island, New Zealand. Geological Society of America Bulletin 93: 625-634.

McLennan, S.M.; Taylor, S. R.; McCulloch, M. T.; Maynard, J.B. 1990. Geochemical and Nd-Sr isotopic composition of deep-sea turbidites: crustal evolution and plate tectonics associations. Geochimica et Cosmochimica Acta 54: 2015-2050.

McLennan, S.M.; Hemming, S.; McDaniel, D.K.; Hanson, G.N. 1993. Geochemical approaches to sedimentation, provenance and tectonics. In Processes controlling the composition of clastic sediments (Johnsson, M. J., Basu, A.; editors). Geological Society of America, Special Paper 284: 21-40.

Millar, I.L.; Pankhurst, R.J.; Vaugham, A.P.M.; Fanning, C.M. 2001. Exotic crustal fragments of the Pacific margin of Gondwana. Comunicaciones (52): 158 p.

Millar, I.L.; Pankhurst, R.J.; Fanning, C.M. 2002. Basement chronology of the Antarctic Peninsula: recurrent magmatism and anatexis in the Paleozoic Gondwana margin. Geological Society of London, Journal 159: 145-157.

Mortimer, N. 1995. Origin of Torlesse terrane and coeval rocks, North Island, New Zealand. International Geology Review 36: 891-910.

Murphy, J.B. 2000. Tectonic influence on sedimentation along the southern flank of the late Paleozoic Magdalen basin in Canadian Appalachians: Geochemical and isotopic constrains on the Horton Group in the St. Mary basin, Nova Scotia. Geological Society of America Bulletin 112 (7): 997-1011.

Mukasa, S.B.; Dalziel, I.W.D. 2000. Marie Byrd Land, West Antarctica: evolution of Gondwana's Pacific margin constrained by zircon $\mathrm{U}-\mathrm{Pb}$ geochronology and feldspar common-Pb isotopic compositions. Geological Society of America Bulletin 112: 611-627.

Nesbitt, H.W.; Young, G.M. 1982. Early Proterozoic climates and plate motions inferred from major element chemistry of lutites. Nature 199: 715-717.

Nesbitt, H.W.; Young, G.M. 1984. Prediction of some weathering trends of plutonic and volcanic rocks based on thermodynamic and kinetic considerations. Geochimica et Cosmochimica Acta 48: 1523-1534.

Nesbitt, H.W.; Fedo, C.M.; Young, G.M. 1997. Quartz and feldspar stability, steady and non-steady state weathering, and petrogenesis of siliciclastic sands and muds. Journal of Geology 105: 173-191.

Nockolds, S.R. 1954. Average chemical compositions of some igneous rocks. Geological Society of America Bulletin 65: 1007-1032.
Olivares, B.; Cembrano, J.; Hervé, F. 2003. Geometría y cinemática de la Zona de Cizalle Seno Arcabuz, Andes patagónicos, Chile. Revista Geológica de Chile 30 (1): 39-52.

Pankhurst, R.J.; Weaver, S.D.; Bradshaw, J.D.; Storey, B.C.; Ireland, T.R. 1998. Geochronology and geochemistry of pre-Jurassic superterranes in Marie Byrd Land, Antarctica. Journal of Geophysical Research 103: 2529-2547.

Pickard, A.L.; Adams, C.J.; Barley, M.E. 2000. Australian provenance for Upper Permian to Cretaceous rocks forming accretionary complexes on the New Zealand sector of the Gondwanaland margin. Australian Journal of Earth Sciences 47 (6): 987-1007.

Rapalini, A.; Hervé, F.; Ramos, V.; Singer, S. 2001. Paleomagnetic evidence for a very large counterclockwise rotation of the Madre de Dios Archipelago, southern Chile. Earth and Planetary Science Letters 184: 471-487.

Roser, B.P.; Korsch, R.J. 1986. Determination of tectonic setting of sandstone-mudstone suites using $\mathrm{SiO}_{2}$ content and $\mathrm{K}_{2} \mathrm{O} / \mathrm{Na}_{2} \mathrm{O}$ ratio. Journal of Geology 94: 635-650.

Roser, B.P.; Korsch, R.J. 1988. Provenance signatures of sandstone-mudstone suites determined using discriminant functions analysis of major element data. Chemical Geology 67: 119-139.

Roser, B.P.; Korsch, R.J. 1999. Geochemical characterization, evolution and source of a Mesozoic accretionary wedge: the Torlesse terrane, New Zealand. Geological Magazine 136 (5): 493-512.

Roser, B.P.; Grapes, R.H.; Palmer, K. 1995. XRF analyses of sandstones and argillites from the Torlesse Terrane, New Zealand. Victoria University of Wellington, Research School of Earth Sciences, Geology Board of Studies Publication 15: 1-40.

Taylor, S.R.; McLennan, S.M. 1985. The Continental Crust: its composition and evolution. Blackwell Scientific Publications: $312 \mathrm{p}$.

Thompson, M.R.A.; Tranter, T.H. 1986. Early Jurassic fossils from central Alexander Island and their geological setting. British Antarctic Survey, Bulletin 70: 23-39.

Thomson, S.N.; Hervé, F.; Fanning, C.M. 2000. Combining fission-track and U-Pb SHRIMP zircon ages to establish stratigraphic and metamorphic ages in basement sedimentary rocks in southern Chile. In Congreso Geológico Chileno, No. 9, Actas 2: 769773. Puerto Varas.

Tranter, T.H. 1991. Accretion and subduction processes along the Pacific margin of Gondwana, central Alexander Island. In Geological Evolution of Antarctica (Thomson, M.R.A.; Crame J.A.; Thomson, J.W.; editors). Cambridge University Press: 437-442.

Vaughan, A.P.M.; Storey, B.C. 2000. The eastern Palmer Land shear zone: a new terrane accretion model for the Mesozoic development of the Antarctic Peninsula. Journal of the Geological Society, London 157: 12431256. 
Vaughan, A.P.M. 2003. Mesozoic terranes in the west Gondwana margin and their implications: an overview of the British Antarctic Survey SPARC Project. In Contribuciones del $10^{\circ}$ Congreso Geológico Chileno, CD-ROM. Concepción.

Wandres, A.M.; Bradshaw, J.D.; Weaver, S.; Maas, R.; Ireland, T.; Eby, N. 2004a. Provenance analysis using conglomerate clast lithologies: a case study from the Pahau terrane of New Zealand. Sedimentary Geology 167: 57-89.

Wandres, A.M.; Bradshaw, J.D.; Weaver, S.; Maas, R.; Ireland, T.; Eby, N. 2004b. Provenance of the sedimentary Rakaia sub-terrane, Torlesse Terrane, South Island, New Zealand: the use of igneous clast compositions to define the source. Sedimentary Geology 168: 193-226.
Willan, R. 2003. Provenance of Triassic-Cretaceous sandstones in the Antarctic Peninsula: implications for terrane models during Gondwana breakup. Journal of Sedimentary Research 73 (6): 1062-1077.

Willner, A.P.; Hervé, F.; Thomson, S.N.; Massonne H.-J. 2004. Converging P-T paths of Mesozoic HP-LT metamorphic units (Diego de Almagro Island, Southern Chile): evidence for juxtaposition during late shortening of an active continental margin. Mineralogy and Petrology 81 (1-2): 43-84.

Veevers, J.J.; Powell, C.; Collinson, J.W.; López Gamundi, O.R. 1994. Synthesis. In Permian-Trassic Pangean Basin and Foldbelts along the Panthalassan Margin of Gonwanaland (Veevers, J.J.; Powell, C.; editors). Geological Society of America, Memoir 184: 11-171. Boulder, Colorado.

Manuscript received: April 7, 2005; acepted: May 30, 2006 